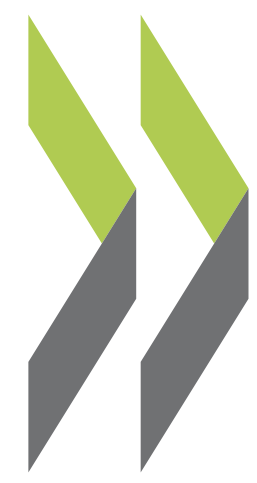

OECD Economics Department Working Papers No. 1125

Strengthening Competition in Poland

\section{Balázs Égert,}

\author{
Antoine Goujard
}


Organisation de Coopération et de Développement Économiques

Organisation for Economic Co-operation and Development

04-Jun-2014

ECONOMICS DEPARTMENT

English - Or. English

STRENGTHENING COMPETITION IN POLAND

ECONOMICS DEPARTMENT WORKING PAPERS No. 1125

By Balázs Égert and Antoine Goujard

OECD Working Papers should not be reported as representing the official views of the OECD or of its member countries. The opinions expressed and arguments employed are those of the author(s).

Authorised for publication by Alvaro Pereira, Director, Country Studies Branch, Economics Department.

All Economics Department Working Papers are available through OECD's Internet website at http://www.oecd.org/eco/workingpapers

JT03358740

Complete document available on OLIS in its original format

This document and any map included herein are without prejudice to the status of or sovereignty over any territory, to the delimitation of international frontiers and boundaries and to the name of any territory, city or area. 
ECO/WKP(2014)21

OECD Working Papers should not be reported as representing the official views of the OECD or of its member countries. The opinions expressed and arguments employed are those of the authors.

Working Papers describe preliminary results or research in progress by the authors and are published to stimulate discussion on a broad range of issues on which the OECD works.

Comments on Working Papers are welcomed, and may be sent to OECD Economics Department, 2 rue André-Pascal, 75775 Paris Cedex 16, France, or by e-mail to eco.contact@oecd.org

This document and any map included herein are without prejudice to the status of or sovereignty over any territory, to the delimitation of international frontiers and boundaries and to the name of any territory, city or area.

The statistical data for Israel are supplied by and under the responsibility of the relevant Israeli authorities. The use of such data by the OECD is without prejudice to the status of the Golan Heights, East Jerusalem and Israeli settlements in the West Bank under the terms of international law.

\section{(C) OECD (2014)}

You can copy, download or print OECD content for your own use, and you can include excerpts from OECD publications, databases and multimedia products in your own documents, presentations, blogs, websites and teaching materials, provided that suitable acknowledgment of OECD as source and copyright owner is given. All requests for commercial use and translation rights should be submitted to rights@oecd.org. 
ECO/WKP(2014)21

\section{ABSTRACT/RÉSUMÉ}

\section{Strengthening competition in Poland}

Poland's productivity has grown strongly over the past decade, and efforts to reduce the regulatory burden have been significant. Despite impressive progress, product market regulation remains more burdensome than in most OECD countries, partly due to the importance of red tape and the level of state involvement in the economy. Further reduction in red tape and pursuing privatisation in competitive markets would increase competitive pressures and ensure neutrality, notably in public procurement processes. Economic rents in many sectors seem high, as stringent entry regulations, regulatory barriers and inefficient bankruptcy procedures induce significant resource misallocation. A welcome deregulation of professional services is ongoing, and the government plans to further ease firm registrations and reform bankruptcy procedures. The independence of the sector regulators in network industries and the powers of the Competition Authority can still be enhanced, as the reform efforts in these sectors remain patchy. The dominant positions of the incumbents and the failure of network sector regulators to introduce a level playing field in order to secure third-party access to the sectoral infrastructure and allow new entry in the competitive segments are another main issue. The advantages of being considered a farmer are also slowing the consolidation process in the agricultural sector. This Working Paper relates to the 2014 OECD Economic Survey of Poland (www.oecd.org/eco/surveys/economic-survey-poland.htm).

JEL classification codes: F43, L1, L3, L4, L5, O3, O43

Keywords: Regulation, competition, Poland, growth, productivity

$* * * * * * *$

\section{Renforcer la concurrence en Pologne}

La productivité de la Pologne a fortement augmenté au cours des dix dernières années et les efforts déployés pour réduire le poids de la réglementation ont été significatifs. Malgré des progrès impressionnants, la réglementation des marchés de produits demeure plus pesante que dans la plupart des autres pays de l'OCDE, ce qui tient en partie à l'importance des formalités administratives et à l'ampleur de l'intervention de l'État dans l'économie. De nouvelles mesures de réduction des formalités administratives et de privatisation sur les marchés concurrentiels accentueraient les pressions de la concurrence et assureraient la neutralité concurrentielle, notamment dans le cadre de la passation des marchés publics. De nombreux secteurs semblent se caractériser par des rentes économiques élevées, dans la mesure où des règles d'entrée rigoureuses, des obstacles réglementaires et des procédures de faillite inefficaces faussent sensiblement l'affectation des ressources. Une déréglementation bienvenue des services professionnels est en cours, et le gouvernement projette d'assouplir encore les procédures d'immatriculation des entreprises ainsi que de réformer les procédures de faillite. L'indépendance des autorités de régulation sectorielles dans les industries de réseau et les prérogatives de l'Autorité de la concurrence peuvent être encore renforcées, étant donné que les efforts de réforme déployés à cet égard demeurent fragmentaires. Un autre problème essentiel tient aux positions dominantes occupées par les opérateurs historiques et au fait que les autorités de régulation sectorielles n'aient pas instauré des règles du jeu équitables, garantissant l'accès des tiers aux infrastructures sectorielles et permettant l'entrée de nouveaux acteurs sur les segments concurrentiels. Les avantages associés au statut d'agriculteur ralentissent par ailleurs le processus de regroupement des exploitations dans le secteur agricole. Ce Document de travail se rapporte à l'Étude économique de l'OCDE de la Pologne 2014 (www.oecd.org/fr/eco/etudes/etude-economique-pologne.htm).

Classification JEL : F43, L1, L3, L4, L5, O3, O43

Mots clefs : Règlementation, concurrence, Pologne, croissance, productivité 


\section{Table of contents}

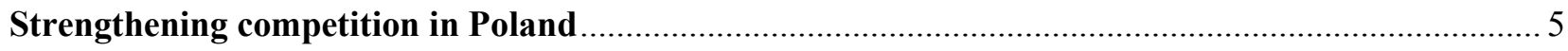

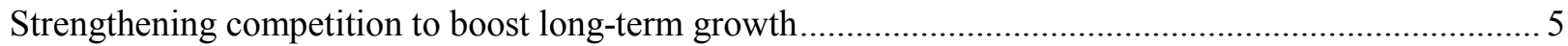

Poland's recent economic performance has been remarkable .............................................................. 5

Pro-competitive structural reforms could boost long-term growth and competitiveness ........................ 6

Product market indicators reveal considerable room for progress................................................... 7

Policies to improve the regulatory framework and product market competition ..................................... 9

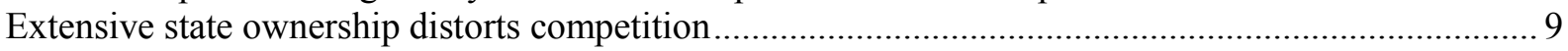

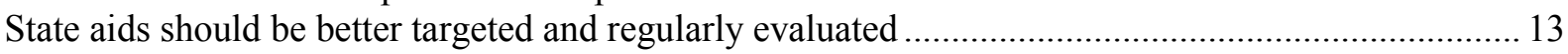

The Competition Authority needs greater independence and further strengthening ............................ 15

Private enforcement of competition laws remains limited .................................................................. 17

Red tape and inefficient bankruptcy procedures slow entrepreneurship ......................................... 18

Improving public procurement capabilities would increase competition .............................................20

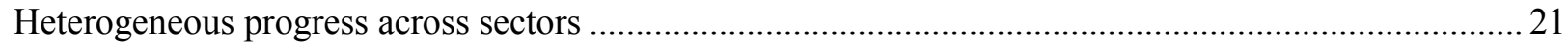

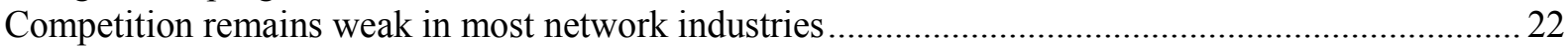

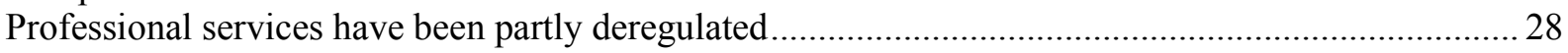

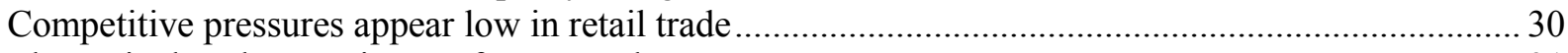

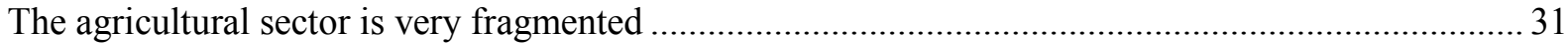

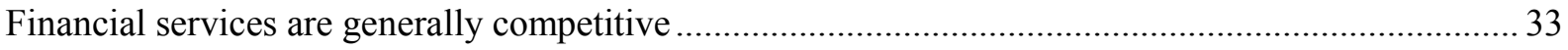

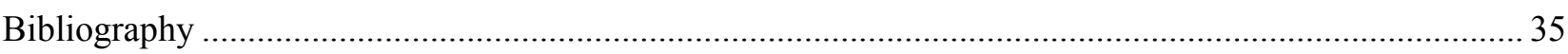

\section{Tables}

1. Forbes Global 2000 SOE sales, profits, market value and assets as a \% GNI, 2011 ................... 12

2. The State intends to retain control of some SOEs even in the long term ................................... 13

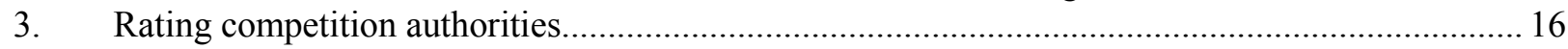

\section{Figures}

1. Average annual GDP per capita growth in OECD countries, 2000-11 ..................................... 6

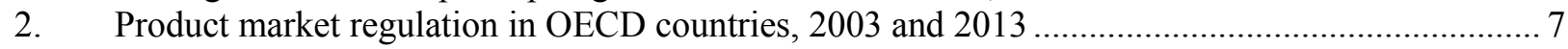

3. Price-cost margins in the whole economy over the $1996-2011$ period......................................... 8

4. Price-cost margins in Poland and comparator countries in 2008-11 ........................................... 9

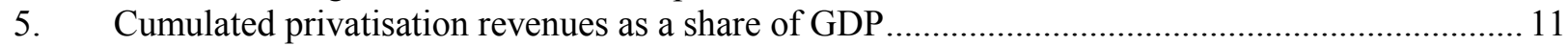

6. Public ownership in the economy, PMR indicators, 2003 and 2013 ....................................... 11

7. Non-crisis state aid is high by European standards and targeted at agriculture and employment.. 14

8. Procedures to start a business and resolve insolvency remain long and costly ............................ 19

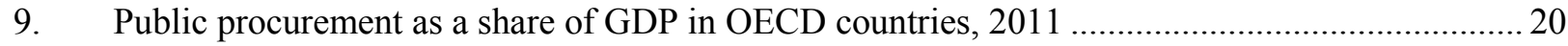

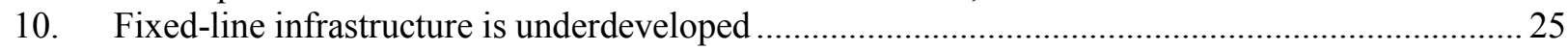

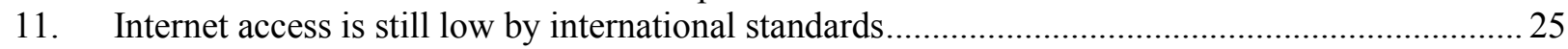

12. The OECD's indicator of the severity of professional services regulation in 2013 .....................29

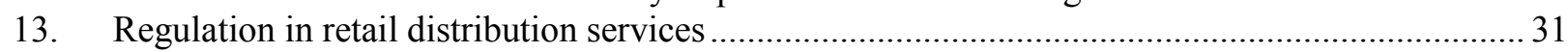

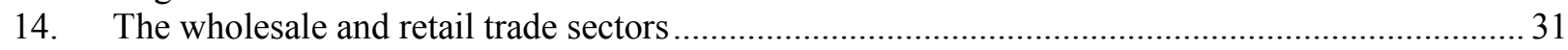

15. Competition distortions contribute to a heavily fragmented agricultural sector ........................... 32

16. Card fees are high by European standards, 2012 …............................................................. 34 
ECO/WKP(2014)21

\title{
Strengthening competition in Poland
}

\author{
By \\ Balázs Égert and Antoine Goujard ${ }^{1}$
}

\section{Strengthening competition to boost long-term growth}

\section{Poland's recent economic performance has been remarkable}

Economic growth has been strong in Poland since the beginning of the transition process. It is the only OECD economy that did not shrink during the global economic crisis of 2007-09. Per capita real GDP growth averaged around 3.8\% between 2000 and 2012, against an OECD average of about $1.6 \%$. Among Central and Eastern European countries (CEECs), only the Slovak Republic and Estonia achieved a similar performance.

Productivity gains explain the major part of the recent growth performance (Figure 1). Per capita income growth can be broken down into the effects of labour utilisation (total hours worked per person), physical capital intensity, human capital and technological progress, so-called multi-factor productivity (MFP) growth (Johansson et al., 2013). While enhanced human capital and better labour utilisation have helped increase per capita income growth, it has been largely impressive MFP outcomes that have driven improved standards of living. Among its OECD peers, only the Slovak Republic recorded stronger productivity growth during this period. Sustained productivity growth is the result of the country's transition from central planning to a market economy and technology transfers from abroad, in part due to Poland's increasing trade openness and integration in global value chains (OECD, 2010a; IMF, 2013a). At the same time, low capital intensity has acted as a severe drag on per capita incomes. By contrast, several other CEECs have benefited from an increase in capital intensity. The negative contribution of physical capital intensity to MFP growth partly reflects the modest level of foreign direct investment (FDI) and the high overall regulatory burden on businesses and investment (Égert and Kierzenkowski, 2013).

1. Balázs Égert is senior economist in the Policy Studies Branch (e-mail: balazs.egert@oecd.org) and Antoine Goujard is economist in the Country Studies Branch (e-mail: antoine.goujard@oecd.org) in the Economics Department of the OECD. This paper was prepared for the OECD Economic Survey of Poland published in March 2014 under the authority of the Economic and Development Review Committee. The authors are particularly thankful to numerous colleagues for their valuable comments, including Hervé Boulhol, Peter Jarrett, Andrew Dean, Robert Ford, Dorothée Allain-Dupré, Rolf Alter, Agustin Diaz-Pines, Sean Ennis, Brendan Gillespie, Andrzej Kwiecinski, Carlo Menon, Krzysztof Michalak, Adam Ostry, Despina Pachnou, Anna Pisarkiewicz, Sam Paltridge, Dirk Pilat and Rudolf van der Berg, as well as to Polish government and central bank officials. The authors are grateful to Patrizio Sicari for excellent research assistance and Mee-Lan Frank for first rate editorial support. 
Figure 1. Average annual GDP per capita growth in OECD countries, 2000-11

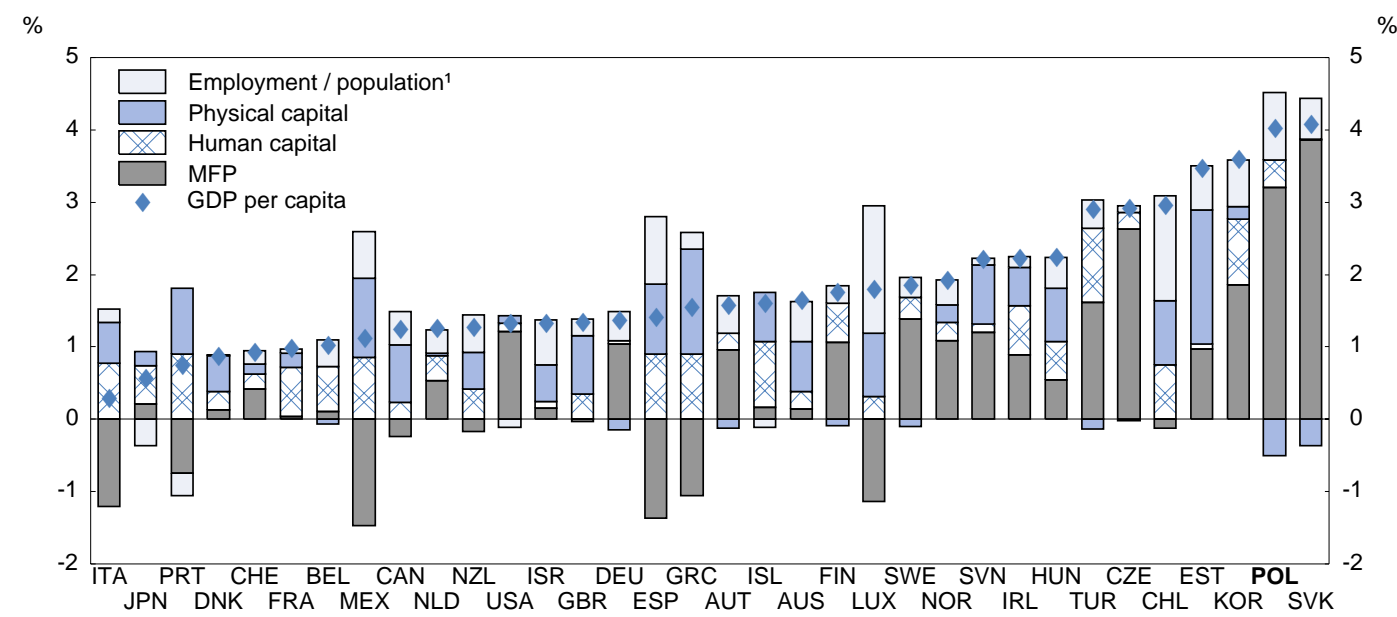

1. To ensure that the percentage gap in the components of GDP add up to GDP per capita the decomposition is done in log differences since the decomposition is multiplicative. GDP per capita is equal to the product of the components MFP, Human capital, (Physical capital/GDP) ${ }^{1 / 2}$ and employment/population.

Source: Johansson et al. (2013), "Long-Term Growth Scenarios", OECD Economics Department Working Paper, No. 1000.

Nevertheless, per capita income was still almost 40\% lower than the OECD average in 2012, mainly because of a shortfall in labour productivity, which was $39 \%$ lower than the OECD average in purchasing power parity terms (OECD, 2013a). Furthermore, over the medium term, the productivity catch-up process could be mechanically slowed by the fast population ageing associated with low fertility rates and a steady rise in life expectancy.

\section{Pro-competitive structural reforms could boost long-term growth and competitiveness}

Speeding up pro-competitive structural reforms could have large long-term beneficial effects on growth and competitiveness. Poland is catching up with the productivity frontier in many sectors, and increasing the level of competition may have especially large productivity payoffs in such a context (Acemoglu et al., 2006). Indeed, sound pro-competition policies and institutions may boost productivity growth and competitiveness through three main channels.

First, stronger competitive pressures would incentivise firms to continuously improve their performance and drive the least efficient firms out of the market. For example, stronger import competition has been shown to increase the productivity of Polish firms through reallocation effects (Goh and Javorcik, 2007). The danger of losing market share to competitors may also increase managers' (and workers') efforts and push firms to adopt better management practices, while allowing owners to better compare and monitor managers (Nickell, 1996; Bloom et al., 2013).

Second, innovation could benefit from stronger competitive pressures, as competition appears weak in most sectors (see below). Rising competition from initially low levels puts pressure on firms to upgrade their technologies and innovate (Aghion et al., 2005; Hashmi, 2013). New entrants may compete by bringing in the latest technologies and push incumbents to invest in human and physical capital, and the pure threat of entry may give incentives to approach the technological frontier (Alesina et al., 2005). Openness to foreign competition through trade and FDI also increases technology transfers within multinational companies and spill-overs to local firms (Nicoletti and Scarpetta, 2005). 
Finally, Poland's productivity may increase via strong spill-over effects across sectors. Product market reforms in upstream industries not only help raise their productivity but also that in those sectors using their outputs (Javorcik, 2004; Goldberg et al., 2010). Recent OECD work showed that Poland has the largest potential in the OECD to increase productivity by aligning product market regulations in network industries, retail distribution and professional services with the average of the three best performing OECD countries (Bourlès et al., 2010; Bouis and Duval, 2011). Though the precise magnitude of this estimate must be interpreted with caution (OECD, 2013b), pro-competitive reforms could lead to a $14 \%$ increase in Polish productivity over a 10 -year period in a fast-implementation scenario.

\section{Product market indicators reveal considerable room for progress}

Poland substantially reduced the burden of Product Market Regulation (PMR) on the economy between 2003 and 2013, according to the OECD's aggregated PMR indicator (Koske et al., 2014). However, product market regulations still appear much more burdensome than in the OECD average country and, in 2013, Greece and Slovenia were the only EU countries having more stringent PMRs (Figure 2).

Progress has been significant but fairly unevenly distributed across different areas. According to the PMR sub-indicators, Poland's competition policy framework (legal barriers, antitrust exemptions, barriers to competition in network sectors and services) was the second least conducive to competition in 2003 but ranked better than the OECD average in 2013. Similarly, government involvement in business operations, such as through command and control regulations, decreased significantly between 2003 and 2013 . Reductions in explicit and implicit barriers to trade and investment have also been impressive, but they remained among the largest in the OECD in 2013. By contrast, progress has been moderate for barriers to entrepreneurship, and Poland still ranks among the worst OECD countries as regards red tape, as measured by the administrative burden on start-ups and regulatory and administrative opacity. Moreover, the government's grip on the economy remains one of the tightest in the OECD. The public ownership sub-indicator was the OECD's highest in 2013, although the privatisation programme, launched in 2008, has continued to reduce public ownership in the economy (see below).

Figure 2. Product market regulation in OECD countries, 2003 and 2013

Index scale from 0 to 6 , from least to most restrictive

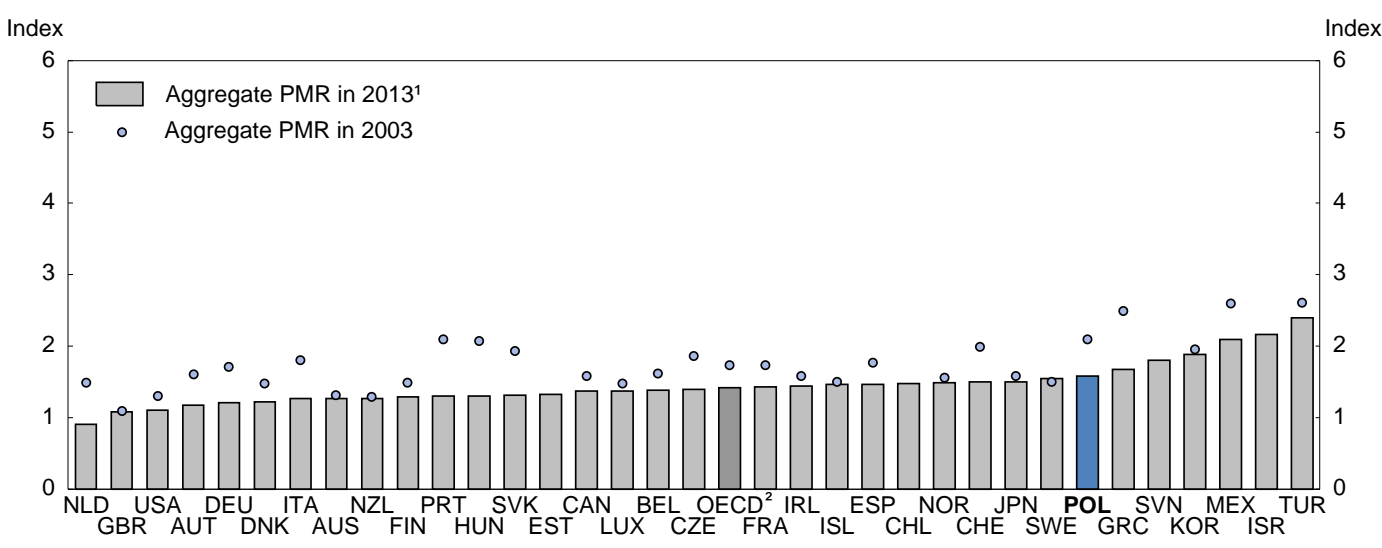

1. 2008 for the United States.

2. The OECD average excludes Chile, Estonia, Israel and Slovenia for which 2003 data are missing.

Source: OECD (2014), preliminary Product Market Regulation database. 
Other indicators of business conditions also highlight that the regulatory burden remains heavy, notwithstanding significant improvements. According to the World Bank's "Doing Business" survey, in 2012, Poland improved the most in the ease of doing business through four reforms: making it easier to register property, pay taxes, enforce contracts and resolve insolvency (World Bank, 2012). However, the survey confirms that administrative costs imposed by regulations still weigh significantly on firms: only nine OECD countries had a lower ranking than Poland in 2013 (World Bank, 2013). Starting a business appears particularly lengthy. According to the survey, there are four procedures to go through, and the process takes nearly a month. A reform of the procedure, approved by the government in early 2014, should reduce the registration time to seven days (Ministry of Justice, 2014). By contrast, it takes only one day to register a new business in New Zealand. Furthermore, Poland still lags behind most OECD countries according to the complexity of the tax system, the difficulties to resolve insolvency or to obtain an electricity connection for a new business (World Bank, 2013).

Market outcomes confirm the existence of severe obstacles to competition and scope for improving economic performance via stronger market discipline. The level of price-cost margins (PCMs, or the Lerner index), a common proxy for the mark-up over marginal costs and the extent of product market competition (Nickell, 1996; Aghion et al., 2005 and 2012; Boulhol, 2010), highlights the importance of competition-restraining regulations in Poland. Indeed, the average PCM of 23 percentage points is 5 to 7 percentage points higher in Poland than elsewhere in the region (Figure 3). PCMs have fallen slightly in Poland since 2003, but their average level in 2011 remained 5 percentage points above the average of the original 15 countries in the euro area (EA15).

Figure 3. Price-cost margins in the whole economy over the 1996-2011 period

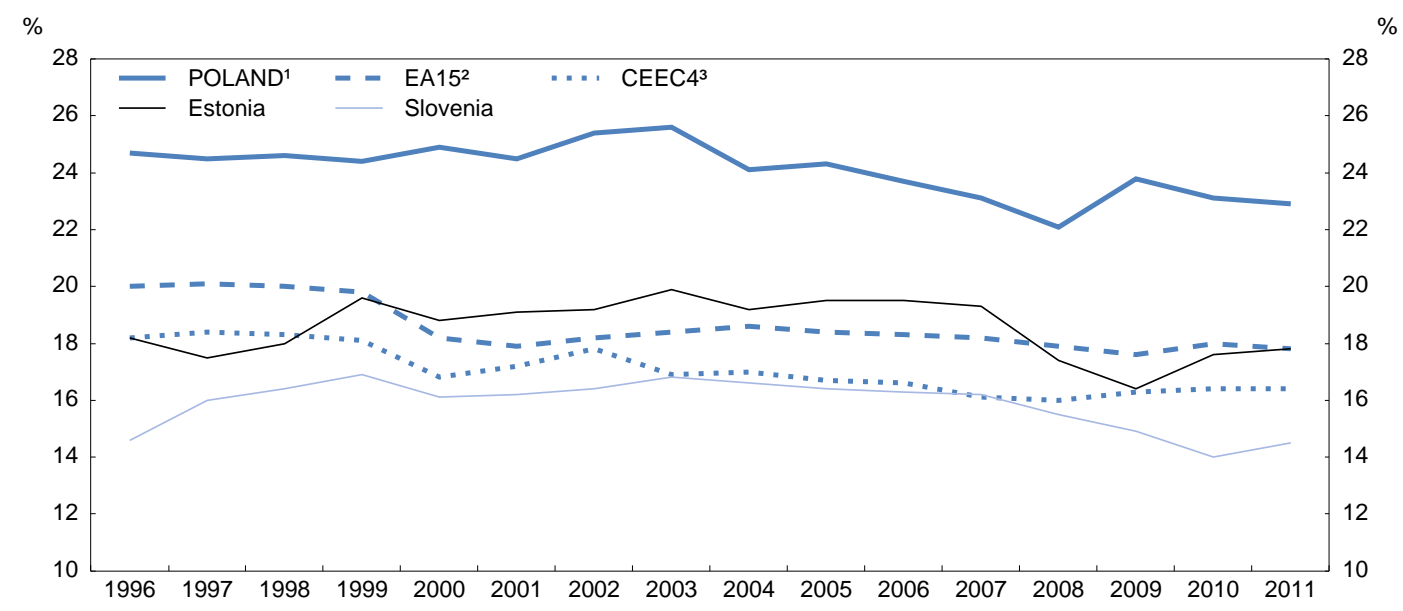

1. Price-cost margins (PCMs) are adjusted for self-employment: self-employed are assumed to earn the average wage in the sector except in the agricultural sector. For each country, the formula used is: $P C M=\left[V A-\sum_{i}\left(L A B R_{i}-L A B R_{i} / E M P_{i} \times S E L F_{i}\right)-L A B R_{a}\right] / O U T P U T$ where $i$ is the sector (excluding agriculture), VA is value added, LABR is labour costs, LABR is labour costs in agriculture, EMP is employment, SELF is self-employment, and OUTPUT is output. Labour costs are not imputed for the large share of self-employed in agriculture (more than $90 \%$ in Poland), which suggests that the contract-based average labour costs would be a poor proxy for the labour costs of the self-employed.

2. EA15 excludes Ireland for which data are missing.

3. CEEC4 excludes Poland.

Source: Eurostat national accounts database and OECD calculations.

The inter-sectoral structure of PCMs in Poland is similar to other CEEC4s (Hungary and the Czech and Slovak Republics) and the EA15's, but their level is higher in all sectors except administrative services (Figure 4). The ratio of price to average costs is determined by competitive pressures and sector-specific production technologies, as described, for instance, by returns to scale and fixed costs. As expected, PCMs 
are low in manufacturing, as foreign competition tends to squeeze margins. By contrast, margins are particularly large in domestically oriented and sheltered sectors.

Figure 4. Price-cost margins in Poland and comparator countries in 2008-11

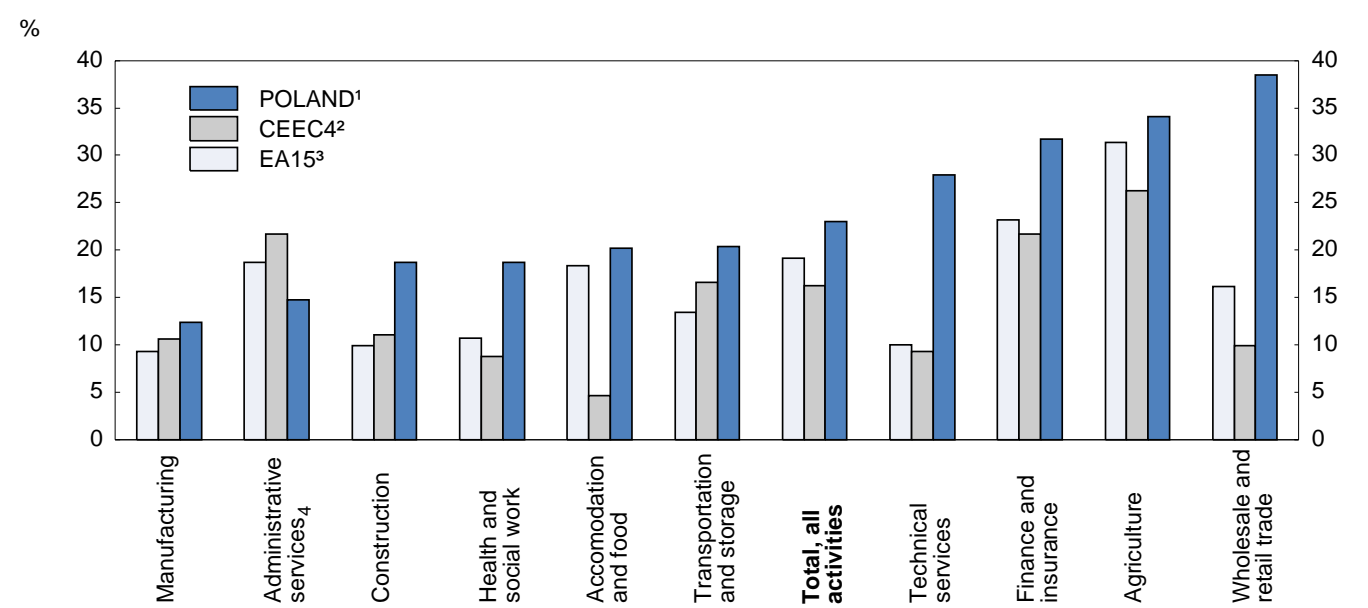

1. The self-employed are assumed to earn the sectoral average wage except in agriculture. Sectors which comprise less than $2 \%$ of Polish employment - mostly public activities (education, public administration and defence) - are not displayed.

2. CEEC4 excludes Poland.

3. EA15 excludes Ireland for which data are missing.

$4 \quad$ Include human resources' activities, office administration, security activities, services to buildings, travel agency services and rental and leasing of motor vehicles, personal and household goods, machinery and equipment, and intellectual property.

Source: Eurostat national account database and OECD calculations.

Poland has recently implemented a broad deregulation of professional services, which should increase competition in this sector (see below). However, competitive pressures are likely to remain weak in other sheltered sectors. In particular, the average mark-up in wholesale and retail distribution is 29 percentage points above the average in the other CEEC4s and 22 percentage points above the EA15 outcome. This indicates that, despite the increasing penetration of chain stores and e-commerce, competition in wholesale and retail activities remains weak. Indeed, retail regulations are as restrictive as in Denmark and France. The most stringent regulation applies to the licensing of new outlets, suggesting that current regulation serves to protect incumbents.

\section{Policies to improve the regulatory framework and product market competition}

Given the high level of regulations and the low level of competition measured by policy indicators and price-cost margins, further increasing market discipline could have large long-term benefits for productivity growth. While public ownership remains widespread, simplifying and rationalising state aids and strengthening the competencies and independence of the Competition Authority could boost competition. Empowering consumers in competition law enforcement, reducing red tape, reforming inefficient bankruptcy procedures and increasing transparency and capacities in public procurement would also increase competitive pressures and improve resource allocation.

\section{Extensive state ownership distorts competition}

There is broad consensus among economists that shifting from public to private ownership tends to increase efficiency and profitability, especially in areas where competitive pressures can be strong (Megginson and Netter, 2001). Privatisation is likely to improve productive efficiency and resource 
allocation across the economy. First, private ownership facilitates and enhances incentives for monitoring managerial performance, based, for instance, on stock and bond prices, because owners can extract the returns to better outcomes, while in state-owned enterprises (SOEs), higher profits belong to taxpayers, who have no direct control over public businesses. The danger of hostile takeovers and bankruptcies and the competitive market for private managers may further push managers to seek to satisfy the profit-maximising objectives set by the owners of privatised firms, rather than to inflate costs through so-called "X-inefficiencies". By contrast, state ownership may provide implicit state guaranties leading to soft budget constraints.

Second, private ownership limits the ability of politicians and pressure groups to distort resource allocation. Polish labour unions wield a non-trivial political influence in mining and transport SOEs, leading to potential cronyism (Capobianco and Christiansen, 2011). Some SOEs have also been shown to have competitive advantages just because of their close ties to local governments (OECD, 2009a). They may receive direct or hidden subsidies incorporated into laws and administrative procedures or public procurement processes (see below). These subsidies are likely to impact on the cost of capital of private firms, possible takeovers and the likelihood of bankruptcies, and ultimately the overall tax burden.

However, privatisation is not always a panacea. For example, network industries have substantial natural monopoly elements, and regulating powerful privatised monopolies poses significant challenges, notably the risk of regulatory capture. Political influence may also persist if the sector regulator is not independent from the government. Furthermore, vertical separation between the potentially competitive parts and the natural monopoly segment, followed by the privatisation of competitive parts, may lead to agency problems. On the one hand, the sector regulator may set access prices that do not cover network costs and discourage investment; on the other hand, prices may also be set too high and lead to overcapacity. Strengthening the independence of the sector regulator and its capacities can reduce the risks of regulatory capture, political influence and agency problems (Nicoletti and Scarpetta, 2003 and 2005).

\section{State ownership remains widespread}

Poland lags behind other CEECs in terms of cumulated privatisation since transition got underway (Figure 5). As a result, public ownership remains one of the most prevalent in the OECD area according to the OECD's PMR indicator (Figure 6). A precondition for a level playing field between SOEs and private firms is that SOEs should at least be corporatised, so that competition, procurement and general bankruptcy laws apply equally to both public and private companies (OECD, 2009a and 2012a). The restructuring of the corporate sector and the privatisation process started very modestly after 1992 and accelerated towards the end of the 1990s with the launch of the mass privatisation programme in late 1994 (OECD, 2010a). In 1990, there were about 8500 state-owned enterprises. By 2012, 2300 of them had been privatised, 1900 liquidated and some 1800 corporatised and commercialised, while less than 400 active enterprises remain in state hands (Ministry of Treasury, 2013a; OECD, 2013c). 
Figure 5. Cumulated privatisation revenues as a share of GDP

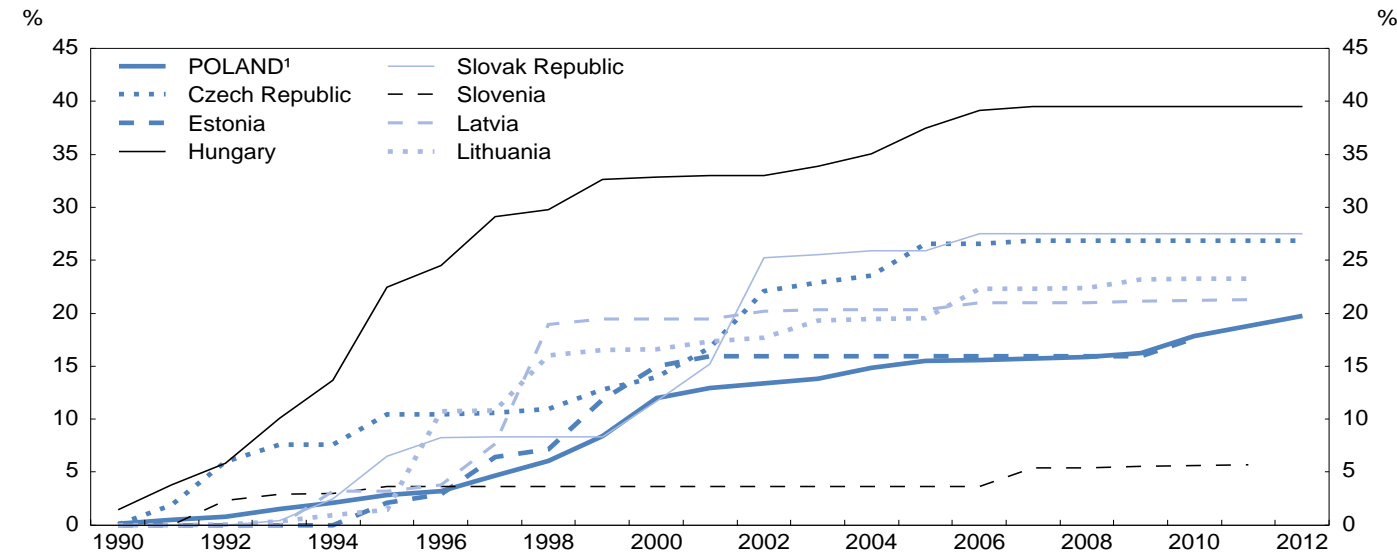

1. Privatisation revenues are computed as a share of GDP of the relevant year and are then cumulated over the years.

Source: World Bank Privatisation Database 1990-2008, World Development Indicators, IMF Article IV reports and CESIFO DICE database.

Figure 6. Public ownership in the economy, PMR indicators, 2003 and 2013

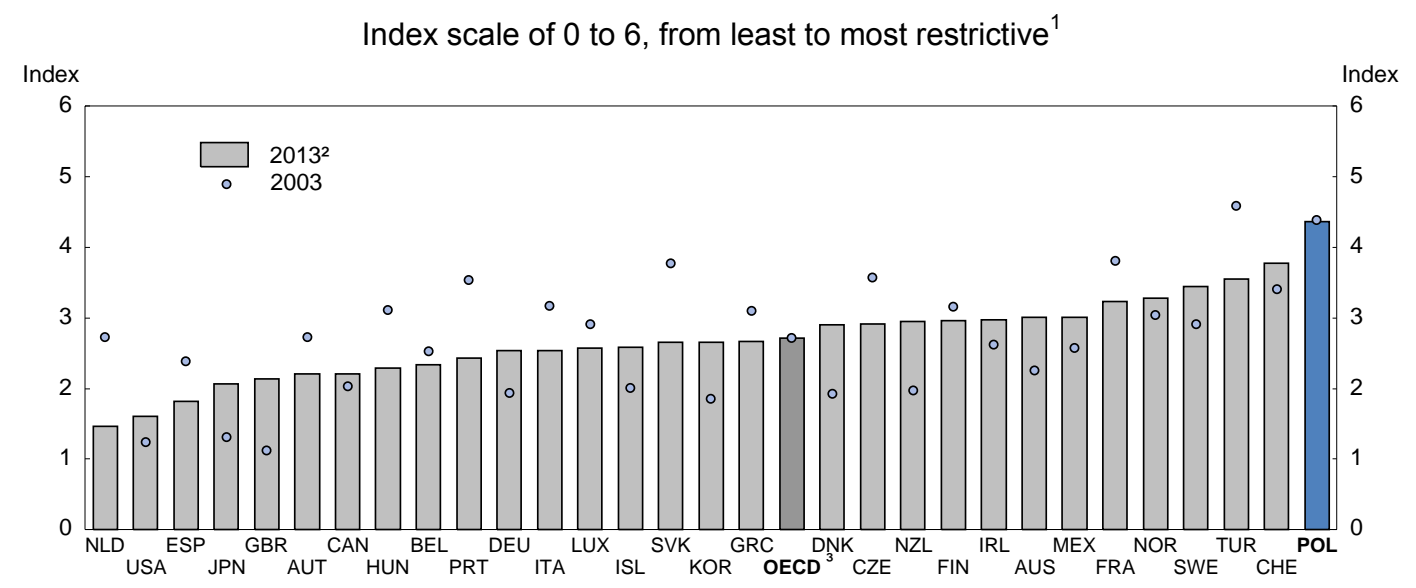

1. The OECD public ownership indicator measures the scope of public ownership in 30 sectors, the extent of state ownership in network industries and the level of public control in enterprises where the state owns shares. The indicator is based on qualitative information, for example the presence or absence of SOEs in a given sector. It measures the scope of public ownership across sectors rather than the quantitative scale of public ownership in the economy.

2. 2008 for the United States.

3. The OECD average excludes Chile, Estonia, Israel and Slovenia for which 2003 data are missing.

Source: OECD (2014), preliminary Product Market Regulation database.

The Polish government plays an important role in many potentially competitive sectors of the economy. Indeed, Poland took the $6^{\text {th }}$ position among OECD countries in terms of the share of SOE employees in total employment in 2008 (Christiansen, 2011). The largest Polish SOEs, which make it to the Forbes Global list, generate sales equivalent to more than $12 \%$ of GNI, their profits reach $1.3 \%$ of GNI, and their market value is around $15 \%$ of GNI (Kowalski et al., 2013). Norway is the only OECD country displaying higher figures, because of its large oil sector (Table 1). Moreover, public ownership concerns not only specific, mostly network, industries, as in many other OECD countries. In 2008, there were indeed over 200 SOEs in manufacturing, employing a total of around 80000 people, more than 100 publicly owned mining companies and almost 30 publicly owned real estate companies (Christiansen, 2011). 
Table 1. Forbes Global 2000 SOE sales, profits, market value and assets as a \% GNI, 2011

\begin{tabular}{lrrr}
\hline & Sales & Profits & Market value \\
\cline { 2 - 4 } & \multicolumn{3}{c}{ Per cent } \\
\cline { 2 - 4 } Norway & \multicolumn{3}{c}{} \\
Poland & 25.0 & 2.1 & 25.9 \\
France & $\mathbf{1 2 . 4}$ & $\mathbf{1 . 3}$ & 14.8 \\
Korea & 7.9 & 0.4 & 7.1 \\
Ireland & 6.8 & 0.2 & 4.0 \\
Greece & 6.5 & -1.9 & 0.3 \\
Czech Rep & 5.8 & 0.4 & 3.8 \\
Sweden & 5.6 & 1.3 & 13.1 \\
Finland & 3.4 & 0.7 & 8.1 \\
Switzerland & 3.3 & 0.7 & 10.6 \\
United Kingdom & 3.1 & 0.6 & 7.1 \\
United States & 2.8 & -0.1 & 3.2 \\
Belgium & 2.7 & -0.1 & 0.4 \\
Austria & 2.6 & 0.9 & 2.9 \\
Turkey & 1.1 & 0.1 & 3.1 \\
Japan & 0.7 & 0.1 & 0.4 \\
Italy & 0.5 & 0.0 & 0.8 \\
Germany & 0.4 & 0.0 & 0.2 \\
\hline
\end{tabular}

Source: Kowalski et al. (2013), "State-owned enterprises: trade effects and policy implications", OECD Trade Policy Papers, No. 147.

Partial privatisation of SOEs raises further challenges for competition in Poland, where the government has often opted to list them on the stock exchange while selling minority or majority stakes in a dispersed way. The method of privatisation has important implications for efficiency improvements, as it gives managers different incentives to restructure the firms (Djankov, 1999). While the overall effect of privatisation on productivity is generally found to be positive in CEECs, a concentrated private ownership structure appears to produce superior economic outcomes compared to dispersed private ownership, presumably because it prevents the state from retaining close control of the firm even if it remains a minority owner (Estrin et al., 2009). In Poland, the "golden veto" legislation of 2005, by which the Treasury was allowed to maintain a privileged position in strategic state-controlled enterprises for public-interest reasons, was abrogated in 2010, as it was viewed by the European Commission as incompatible with EU law (OECD, 2010a). However, the Polish state has kept a controlling stake in many companies by remaining a majority owner or a large minority owner. This form of state-controlled privatisation may result in much lower efficiency improvements than full privatisations. Indeed, state-controlled firms may benefit from the same competition distortions as SOEs relative to private firms.

\section{Government involvement in the economy is likely to remain high}

The government launched ambitious privatisation plans in 2008-11, targeting the sale of around 800 companies, and 2012-13, and the process is still on-going. The privatisation process accelerated in $2010-11$, as proceeds increased from $0.2 \%$ of GDP in 2008 to $1.0 \%$ in 2011 , and additional revenues of about $0.2 \%$ of GDP per year were expected by the government in 2013 and 2014. However, the government classified almost 50 SOEs as strategically important and intends to keep them under majority state ownership, or to sell tranches in such a way that it can maintain control due to dispersed ownership (Ministry of Treasury, 2013b). These SOEs operate mostly in the energy, financial and mining sectors. Table 2 below gives a selected list. The government also wants to maintain control over companies in the chemicals and mining industries, which are not deemed as strategically important. 
Table 2. The State intends to retain control of some SOEs even in the long term

Selected list of state-owned enterprises in which the State wants to keep a controlling stake

\begin{tabular}{|c|c|c|c|}
\hline \multirow[t]{2}{*}{ Company } & \multirow[t]{2}{*}{ Sector } & $\begin{array}{c}\text { State ownership } \\
2013 \\
\end{array}$ & $\begin{array}{c}\text { Targeted state } \\
\text { ownership }\end{array}$ \\
\hline & & \multicolumn{2}{|c|}{ Per cent } \\
\hline \multicolumn{4}{|l|}{ Strategic companies } \\
\hline PGE & Energy & 62 & 50 \\
\hline Tauron & Energy & 30 & 25 \\
\hline PKO BP & Banking & 31 & 25 \\
\hline PZU & Insurance & 35 & 25 \\
\hline KGHM & Metals mining & 32 & 32 \\
\hline PGNiG & Oil \& gas & 72 & 72 \\
\hline PKN Orlen & Oil \& gas & 28 & 28 \\
\hline Grupa Lotos & Oil \& gas & 53 & 53 \\
\hline \multicolumn{4}{|c|}{ Keeping control over non-strategic companies } \\
\hline Grupa Azoty & Chemicals & 33 & 33 \\
\hline JSW & Mining - coal & 56 & 34 \\
\hline Komnpania Weglowa - NL & Mining - coal & 100 & 50 \\
\hline Katowicki holding Weglowy - NL & Mining - coal & 100 & 50 \\
\hline \multicolumn{4}{|c|}{ Disengagement from non-strategic companies } \\
\hline Ciech & Chemicals & 39 & 0 \\
\hline ENEA & Energy & 52 & 0 \\
\hline WSE & Financial sector & 35 & 0 \\
\hline PHN S.A. & Real estate & 75 & 0 \\
\hline Energa - NL & Energy & 84 & 0 \\
\hline Weglokoks - NL & Trading - coal & 100 & 0 \\
\hline
\end{tabular}

Source: Ministry of Treasury (2013b), Poland: Privatisation plan \& investment opportunities, June.

In late 2012, the Prime Minister announced the creation of the Polish Investment Programme, which will use future privatisation revenues (and also government assets, including SOE holdings) to co-finance investments in infrastructure, estimated at about 30\% of GDP, and in chemicals, energy, transport and telecommunications industries (Ministry of Treasury, 2013). If such a programme may be justified by the need to remedy market failures in terms of the weak market availability of long-term finance for infrastructure projects, which would therefore stimulate economic growth, it could also mean further state involvement in some competitive sectors of the economy.

The maintenance of majority state ownership in some companies in competitive segments of the economy may limit the potential benefits of the 2008-11 and 2012-13 privatisation plans. While the government wishes to improve the efficiency of these companies through enhancing corporate governance standards rather than via privatisation, changes in the government's priorities may make such advances easily reversible and may question the independence of the managing board. For example, the Treasury recently expressed its desire to tighten its control over a number of SOEs through their supervisory boards (Polish News Bulletin, 2013b). In sum, the government should significantly reduce state ownership in competitive markets, such as financial institutions, mining and chemical companies, while ensuring sound governance of the remaining SOEs.

\section{State aids should be better targeted and regularly evaluated}

State aid, including subsidies and tax expenditures aimed at specific sectors and firms, could also contribute to competition distortions. The most frequent forms of state aid are tax concessions and grants, which represented around 97\% of aid in 2011 (UOKIK, 2012). State aid, as recorded by the European Commission, appears high by European standards, though its share as a percentage of GDP decreased between 2002 and 2011 (Figure 7, Panel A). State aid regulation in Poland is consistent with EU law. 
Competition-distorting aids are banned, but exceptions for rescuing firms, restructuring distressed sectors and regions, promoting SME growth, and fostering employment and lifelong training are permitted. To ensure equal competition, state aid schemes or changes to the conditions for its use require notification to the European Commission. The only exceptions are aid granted under the so-called block exemptions and de minimis aid. Block exemptions aim to foster job creation, competitiveness and SMEs, which are considered to be compatible with state aid rules without requiring prior notification. Cumulated de minimis aid per firm must not exceed EUR 200 000gross value (or EUR 100000 in the case of road transport) over three consecutive calendar years.

Figure 7. Non-crisis state aid is high by European standards and targeted at agriculture and employment

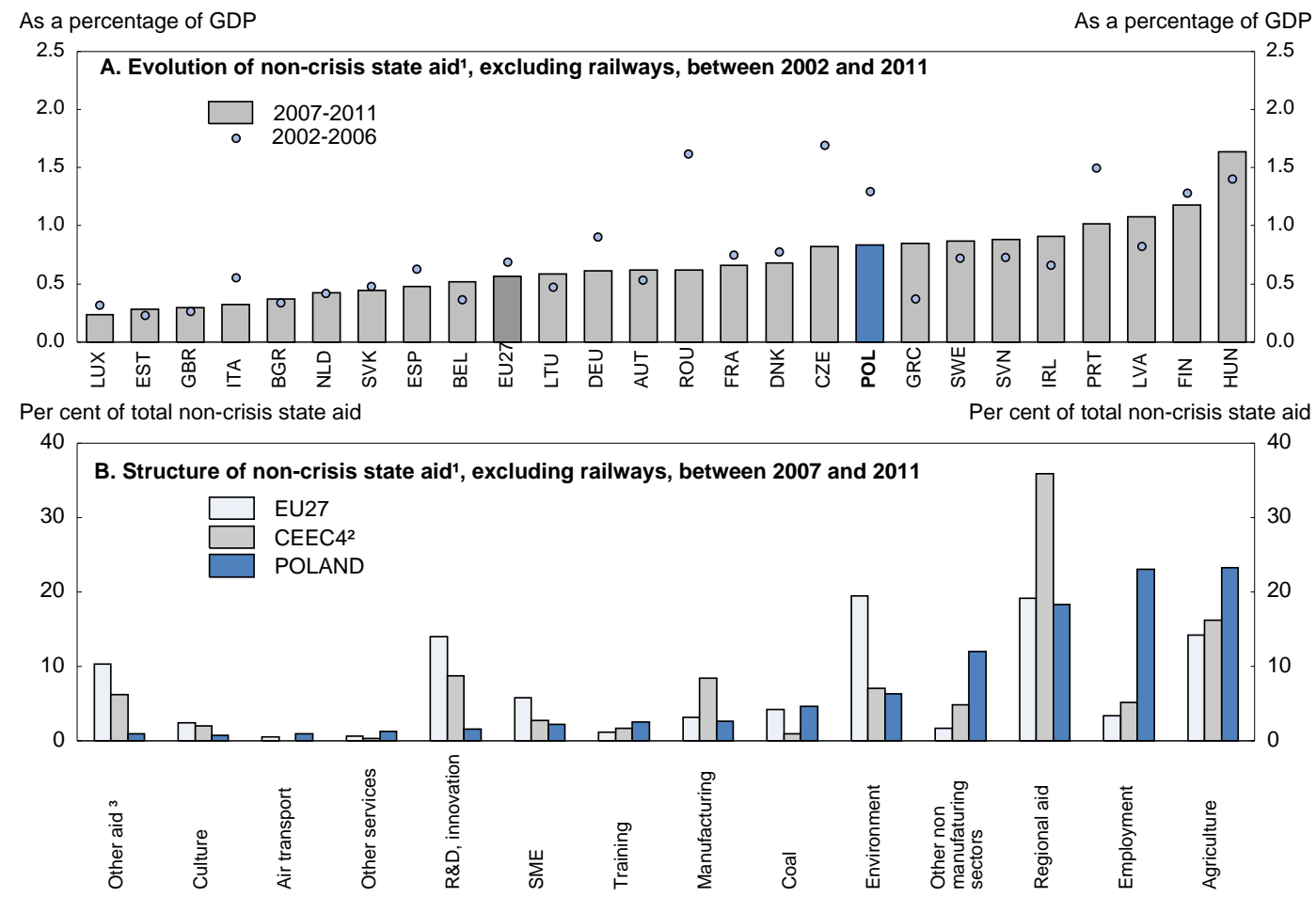

1. Non-crisis state aid excludes financial crisis aid and temporary framework aid granted from 2008 to 2011 . It refers to measures authorised by the European Commission decisions or being implemented by Member States under block exemption. It excludes measures that do not favour certain enterprises or sectors, and public subsidies that do not affect trade or distort competition.

2. CEEC4 is the unweighted average of Hungary and the Czech and Slovak Republics.

3. Other aid regroups residual forms of aid, which represent less than $1 \%$ of granted aid in Poland.

Source: European Commission (2012c), "Facts and figures on State aid in the EU Member States", Commission Staff Working Paper, No. 778.

State aid may help correct market failures and enhance economic growth and efficiency, but it may also be influenced by pressure groups and lead to resource misallocation (OECD, 2010b; Aghion et al., 2012). At the aggregate level, it appears aimed at sustaining the agricultural sector and maintaining employment, notably for disabled persons, while support to research and development and innovation and environmental aid play lesser roles than in the EU27 and the other CEEC4s (Figure 7, Panel B). At the microeconomic level, state aid also appears dispersed across granting institutions and recipients. Indeed, a large number of organisations are responsible for state aid attributions. In 2011, 831 organisations, including ministries, public bodies and local governments (389), granted state aid to around 81000 beneficiaries (UOKIK, 2012). Though the Competition Authority records granted aids, the dispersion of aid suggests that reducing the number of granting institutions could increase its cost effectiveness and ease its monitoring and economic evaluation. 
Another main issue with state aid in Poland is the lack of assessment of its economic effects, which may include competition distortions. The impact of existing state aids should be carefully analysed, and any additional aids should address specific market failures, minimise moral hazard and adverse selection risks, and avoid distorting competition or crowding out private financing. One important example is the Special Enterprise Zone (SEZ) programme. In Poland, investors have benefited from incentives to locate their activities in 14 SEZs since 1994 as part of regional policies to fight high structural unemployment in some peripheral areas. Benefits consist of tax reductions, assistance in handling formalities, availability of land at below-market prices and real estate tax exemptions (OECD, 2010a). The SEZ programme's expiry was recently extended from 2020 to 2026. However, their economic effects have yet to be evaluated, and the programme has been criticised by the Ministry of Finance for its inability to improve regional growth (Ministry of Finance, 2013). Even though the programme may have been partly successful at attracting FDI and motivated by tax competition with Hungary and the Czech and Slovak Republics, it may generate large deadweight losses through competition distortions (OECD, 2010a). Indeed, empirical evidence regarding the effects of such economic zones in France and the United Kingdom is mixed. It suggests that they may in some cases be cost effective, while in others large displacement effects - without economic gains - may occur through competition distortions involving domestic firms located nearby (Criscuolo et al., 2012; Mayneris et al., 2012).

\section{The Competition Authority needs greater independence and further strengthening}

Poland has gone a long way in setting up well designed competition policies and ranks above the OECD average according to the 2013 OECD indicators of Competition, Law and Policy (CLP). After the start of transition, competition policy focused on monitoring market dominance of traditional state monopolies including infrastructure providers. Over the years, monitoring anti-competitive state aid also became a priority (Wise, 2003). The Competition and Consumer Protection Law of 2007 represented an important upgrade of the framework, unifying competition rules on antitrust (vertical and horizontal agreements and abuse of dominant position) and mergers. As a result, the scope of competition law activities, the processing of alleged anticompetitive behaviour and the capacity to advocate competition at different levels of government appear above the OECD average according to the 2013 CLP indicators. Nevertheless, information regarding the way in which alleged anticompetitive behaviour is tackled by the Competition Authority could be further developed, as there are no official publications explaining the assessment of alleged anti-competitive behaviour, such as abuse of dominance and horizontal and vertical agreements (Alemani et al., 2013).

Overall, the Competition Authority is perceived as an efficient competition enforcer, despite the weak competitive pressures in the economy (see above) and its limited budget. According to the 2013 edition of the Rating Enforcement of the Global Competition Review (Global Competition Review, 2013), which is based on a survey sent to antitrust lawyers, academics and journalists, the Polish Competition Authority received a three-star rating (out of a maximum of five). The enforcement of competition policy in Poland is considered similar to that in the Czech Republic, Finland or Sweden but significantly below that in France, Germany, the United Kingdom or the United States (Table 3). The Review points out that the size of a competition authority and its budget are correlated with its rating. The Polish Authority is not particularly big, and its budget is also not large: with about 130 people working on competition, its staff is small in absolute terms and represents a smaller share of total employment than in many other countries. Taken at face value, this indicates that allocating more resources to the agency could improve competition enforcement in Poland. 
Table 3. Rating competition authorities

\begin{tabular}{|c|c|c|c|}
\hline \multicolumn{2}{|c|}{ Elite (5 stars) } & \multicolumn{2}{|r|}{ Very good (4 stars) } \\
\hline European Commission & DG Competition & Japan & Fair Trade Commission ( $4 \frac{1}{2}$ stars) \\
\hline France & Competition Authority & Australia & Competition \& Consumer Commission \\
\hline Germany & Federal Cartel Office & Brazil & CADE \\
\hline United Kingdom & Competition Commission & Netherland & Competition Authority \\
\hline United States & $\begin{array}{l}\text { Department of Justice's antitrust } \\
\text { division }\end{array}$ & Spain & National Competition Commission \\
\hline United States & Federal Trade Commission & United Kingdom & Office of Fair Trading \\
\hline \multicolumn{2}{|c|}{ Good (3 stars) } & \multicolumn{2}{|r|}{ Fair (2 stars) } \\
\hline Canada & Competition Bureau (31/2 stars) & Belgium & Competition Authority (21/2 stars) \\
\hline Italy & Competition Authority (31/2 stars) & Chile & $\begin{array}{l}\text { National Economic Prosecutor's Office } \\
\left(2 \frac{1}{2} \text { stars }\right)\end{array}$ \\
\hline Korea & Fair Trade Commission (31/2 stars) & Denmark & Competition and Consumer Authority ( $21 / 2$ stars) \\
\hline New Zealand & Commerce Commission (31/2 stars) & Mexico & Federal Competition Commission ( $21 / 2$ stars) \\
\hline Austria & Competition Authority (31/2 stars) & Pakistan & Competition Commission (21/2 stars) \\
\hline The Czech Republic & $\begin{array}{l}\text { Office for the Protection of } \\
\text { Competition }\end{array}$ & Turkey & Competition Authority (new entrant) (21/2 stars) \\
\hline Finland & Competition Authority & Lithuania & Competition Authority \\
\hline Greece & Competition Commission & & \\
\hline Hungary & Competition Authority & & \\
\hline Ireland & Competition Authority & & \\
\hline Israel & Antitrust Authority & & \\
\hline Norway & Competition Authority & & \\
\hline Poland & $\begin{array}{l}\text { Office of Competition and } \\
\text { Consumer Protection }\end{array}$ & & \\
\hline Portugal & Competition Authority & & \\
\hline Russia & Federal Antimonopoly Service & & \\
\hline South Africa & Competition Commission & & \\
\hline Sweden & Competition Authority & & \\
\hline Switzerland & Competition Commission & & \\
\hline
\end{tabular}

Source: Global Competition Review (2013), Rating Enforcement 2013.

Besides the Authority's limited resources, competition enforcement in Poland faces four serious challenges. The first concerns the current legal framework which offers little power to the Competition Authority as regards the enforcement of structural remedies. The Competition Authority can start a market study and publish its conclusions, but it cannot, for instance, split up dominant firms. This is an important issue in some sectors, such as telecommunications, energy, railways, air transport and airports, in which market concentration is high and firms are mostly state owned. For example, the Authority cannot force the vertical separation of companies if they abuse their monopoly power in terms of third-party access to their network infrastructure (such as the gas and electricity transmission and distribution networks). This stands in contrast with countries like Austria, Canada, Germany, Ireland, Japan the United Kingdom and the United States, where structural separation remedies are available under national competition law (OECD, 2012b). A welcome draft amendment would give the Authority more power to reduce market power and SOE monopoly rents through structural remedies.

A second challenge relates to cartel cases and inefficiencies in the legal system. Concerned parties can appeal the Competition Authority's decisions first in a court specialised in competition issues and then, in a 
second instance, in a "normal" court. The time lapse between a first decision and a final court ruling can thus be very long. While this is certainly not a major problem for mergers, as they are not allowed to take place before the final ruling, the long delay may have important economic consequences in the case of cartels, given that cartels can continue operating throughout the period up to the final ruling. For instance, no final legal decision has been made thus far in the case of an alleged cement industry cartel reported by the Competition Authority in 2009. Developing information and communication technology use would help to reduce the length of court procedures (Palumbo et al., 2013).

A third challenge is that the political independence of the president of the Competition Authority is not fully guaranteed, despite important improvements. While the Competition Authority has shown considerable independence in its decisions in individual cases (Wise, 2003), an amendment to the 2007 Competition Act transformed the five-year mandate of the President into an open-ended contract. The incoming Prime Minister in 2008 used this opportunity to nominate a new head who was in turn dismissed in February 2014. The open-ended contract and the fact that its President can be recalled without justification potentially expose the Competition Authority to political pressures. It would be useful for the President to have a non-renewable fixed-term tenure of five or six years, straddling electoral cycles, and a contract ensuring he or she cannot be dismissed without fault. At the same time, it needs to be acknowledged that a formal competitive recruitment process for the nomination of a new President and eligibility criteria, such as professional experience and education, have been put in place to ensure high professional competence and transparency. The Prime Minister can choose only from three candidates short-listed by a group of experts who are nominated under his/her authority. The group of experts has to justify the non-selection of candidates for the short list in writing, with the names of the short-listed candidates being published in an official government journal.

Finally, the leniency programme implemented in 2004 to fight cartels could provide greater incentives. Leniency, which gives immunity or reduced fines for cartel participants for disclosing information, is an important tool in the fight against cartels. Between 2004 and 2011 the Competition Authority received only 30 applications for leniency, but 16 firms applied to the programme in 2012 (UOKIK, 2013). A recent draft amendment to the Competition Act prepared by the Authority would enhance the functioning of the leniency programme by increasing rewards to cartel participants who report them. The Polish "leniency plus" programme, inspired by US legislation, would offer a reduction in fines for those cartel participants who were the second or third to report the existence of a cartel, and thus do not qualify for the initial leniency, if they report another cartel agreement. The amendment would also increase the incentives of natural persons including managers and sales representatives to provide evidence of cartels. While under the current legislation the liability of natural persons, such as executives and managers of cartel members, is limited to procedural violations, the draft amendment would expand their liability to anti-competitive conduct, allowing the Authority to impose fines on them of up to PLN 2 million (about half a million euros) but also to grant them leniency.

The draft amendment also comprises other important improvements: the simplification and shortening of antitrust procedures and the inclusion of a list of possible remedies the Competition Authority may enforce to remove barriers to competition. In particular, it would introduce structural remedies to enforce competition policy (see above). A further improvement proposed is the simplification and acceleration of the merger-review process, which would make it easier to concentrate on the potentially most harmful deals.

\section{Private enforcement of competition laws remains limited}

Private enforcement involves actions brought by private individuals before the ordinary courts seeking compensation for losses incurred as a result of breaches of competition law. Public enforcement has historically been dominant in Poland, and consumers rely heavily on the Authority to control 
anti-competitive behaviour. When it was first established in 1990, the main task of the Competition Authority was to enforce competition law; it became responsible for the protection of consumer interests only in 1996. Indeed, there is substantial empirical evidence that strengthening consumers' rights, protection and information increases competition (OECD, 2008b). The enforcement of both policies under one roof provides for a high level of co-ordination of enforcement activities. The antitrust act on the basis of which the Authority has been operating since April 2007 enables it, inter alia, to impose financial penalties amounting to $10 \%$ of violators' net income from the previous year on undertakings applying practices infringing consumers' collective interests.

As gathering evidence is rather difficult and the proceedings are costly in competition cases, private enforcement of competition law is bound to be limited in most countries. Consumer organisations and class actions can encourage private claimants to undertake legal actions (OECD, 2011a). The notion of class actions was introduced into Polish law in July 2010 in accordance with the Act of December 2009 on collective redress (OECD, 2011b). Consumers and entrepreneurs can seek such redress for common damage. The Act does not limit consumer claims as to their object, and they could result from antitrust infringements and competition law violations. For example, in July 2013, the court found that BRE Bank unlawfully collected portions of loan instalments from a group of 1247 consumers and awarded refunds with statutory interest. It is one of the first class-action lawsuits filed in Poland and the largest in terms of the number of claimants. However, competition infringements remain scarce, with only one class action filed for misleading advertising among the over 40 class actions undertaken in 2010-11 (Piscz, 2012; Tulibacka and Goral, 2013). The small number of judges qualified to examine competition law cases, potential plaintiffs' limited knowledge of the relevant procedures and the absence of punitive damages partly explain the overall limited development of private enforcement (European Commission, 2008).

\section{Red tape and inefficient bankruptcy procedures slow entrepreneurship}

Competition and entrepreneurship suffer from a number of barriers to the entry and exit of firms. Indeed, empirical cross-country evidence suggests that red tape acts as a drag on firm and job creation (Ciccone and Papaioannou, 2007). The government estimates the administrative burden imposed upon business by regulation at more than 5\% of GDP per year (OECD, 2012c). Red tape and cumbersome registration processes are likely to weigh particularly on foreign companies' penetration by FDI or otherwise. Attracting more internationally mobile investors will require improving the business environment. In particular, some regulations applying to professional services may hinder foreign competition. For example, the European Commission (2012a) argues that Poland's poor transposition of the single-market legislation negatively affects the business environment, in particular for foreign companies. Although Poland transposed the Services Directive, the effect of the resulting horizontal law on a number of sectoral acts remains uncertain, especially with respect to the cross-border provision of services such as education and tourism (for example, establishment, registration requirements and obligation to possess a special identity document).

The government has launched a programme aimed at reducing red tape (OECD, 2012c). In 2011 several significant improvements to economic law and business registration procedures were implemented. They aim to cut red tape for setting up and running businesses by replacing around 200 administrative certificates by self-certifications and by reducing the number of documents needed for starting a business. The information obligations required to run a business have also been cut. However, the registration time for companies to be allowed to operate is still long. While new firms have been able to register on the Internet since mid-2011 and the time needed for the registration of limited liability companies is now one day, the usual cost and time required to start a business measured by the World Bank Doing Business survey remain high by OECD standards (Figure 8, Panel A). The government plans to further ease the administrative burden by implementing new streamlining measures and by reducing the paperwork related to the collection of taxes and social security contributions. For example, welcome e-procedures would 
allow new entrepreneurs to submit a unique application for the business register, the revenue office, the social security agency and the statistical agency (Polish News Bulletin, 2014).

Figure 8. Procedures to start a business and resolve insolvency remain long and costly

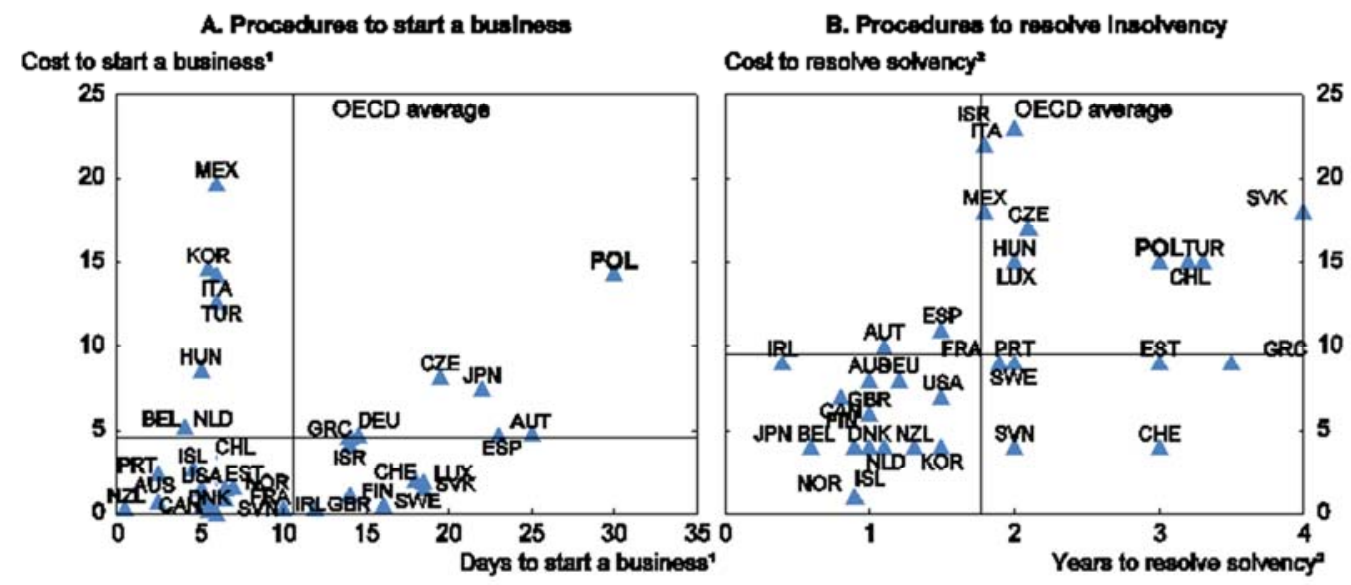

Note: Vertical and horizontal lines represent the OECD average process length and costs, respectively.

1. The cost to start a business is recorded as a percentage of the economy's annual income per capita. It includes all official fees and fees for legal or professional services if such services are required by law. Time to start a business captures the median duration that incorporation lawyers indicate is necessary in practice to complete a procedure with minimum follow-up with government agencies and no extra payments.

2. The cost of the insolvency proceedings is recorded as a percentage of the value of the debtor's estate. Time to resolve insolvency represents the time for creditors to recover their credit in calendar years. The period of time measured by Doing Business is from the company's default until the payment of some or all of the money owed.

Source: World Bank (2013), Doing Business, 2014.

Time-consuming and costly bankruptcy proceedings also deter entrepreneurship and limit the ability to save viable businesses, especially during economic downturns. They may also hamper the exit of inefficient businesses, limiting resource reallocation. The most important feature of a good bankruptcy regime is that it deals with problems clearly, fairly and expeditiously. If it is also lenient toward indebted companies, that has advantages for entrepreneurship in that it reduces the costs of failure and hence the downside risks, while allowing debtors to recover and undertake new initiatives. This, however, must be weighed against the disadvantages in terms of availability of capital due to weaker creditors' rights (Bravo-Biosca et al., 2013). Poland does not compare favourably here (Figure 8, Panel B). The World Bank Doing Business survey suggests that the bankruptcy process takes about a year more than in the average OECD country and that the cost is also far higher. The bankruptcy proceedings remain open as long as valid creditor claims are outstanding, and hence the process can be lengthy. Only when it is completed, and assuming there are no issues of bad faith, can the bankrupt party start a new business. The result of these arrangements is that relatively few bankruptcies occur. In 2012, 4313 entrepreneurs filed for bankruptcy, but only 916 were declared. Encouragingly, the stigma of bankruptcy seems to have been reduced, and Polish society appears increasingly inclined to allow a "second chance" for entrepreneurs who have previously gone bankrupt (European Commission, 2012b). Furthermore, in 2014, a planned reform of bankruptcy procedures would allow companies to undertake early restructuring procedures, introduce simplified arrangements and develop second-chance policies.

Natural persons operating a business in sole proprietorship may file for bankruptcy only under business law as personal bankruptcy law does not apply to entrepreneurs (OECD, 2010b; Ministry of Economy, 2012). As lenders to small businesses often require that the owner provide a personal guarantee for the loan, such as a second mortgage on his/her house, the personal guarantee of a firm's owner and the 
level of outstanding debt in case of business failure may effectively prevent entrepreneurs from creating a new firm and discourage firm entry (Polish Agency for Enterprise Development, 2011).

\section{Improving public procurement capabilities would increase competition}

The design and implementation of public procurement policies have important implications for product market competition, public finances and long-term growth. In Poland, general government public procurement is estimated to have accounted for more than 13\% of GDP in 2011; if public procurement by SOEs is also taken into account, it would have been around 19\% of GDP (Figure 9). The amounts involved in public procurement contracts are substantial: contracts awarded according to Polish public procurement law amounted to 9.5\% of GDP in 2011 (Public Procurement Office, 2012). If public procurement does not ensure competitive neutrality, i.e. the selection of suppliers with the best combination of prices and quality, incentives for firms to compete are significantly reduced. Moreover, distorted public procurement policies have a detrimental indirect impact on long-term growth, as they often concern physical infrastructure that has a great impact on international competitiveness (OECD, 2011c). In addition to getting the general competition policy framework right, including criminal justice provision, the OECD recommends a set of rules on the optimal design of public procurement to reduce anticompetitive behaviour (collusion) and corruption. Generally, these should be accompanied by national market opening to international competition, increased e-procurement, expanded education of public officials, a systematic review of public-contract awards and the auditing of public-procurement procedures (OECD, 2011c). In Poland, public procurement is open to international competition, and the Public Procurement Office controls contract awards and procedures, but some specific factors hinder the efficiency of public procurement practices.

Figure 9. Public procurement as a share of GDP in OECD countries, 2011

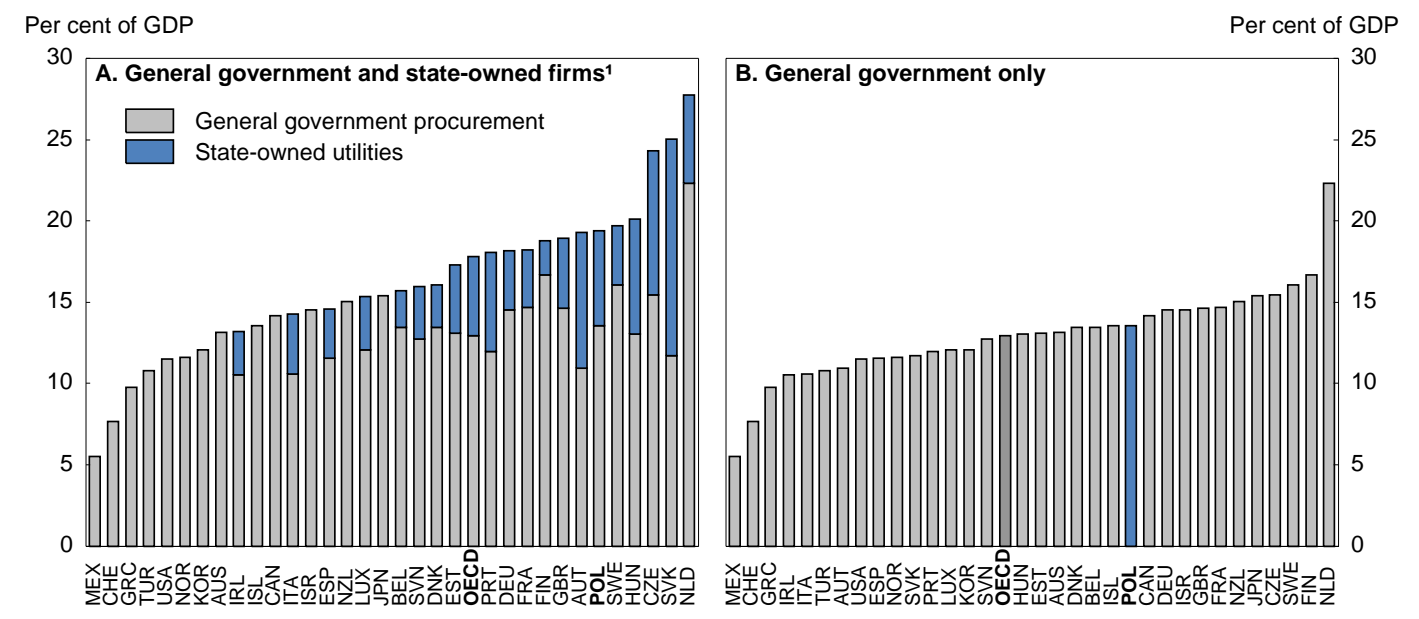

1. Data for public procurement of state-owned enterprises refer to 2008. Estimations of the public procurement transactions of state-owned utilities are available only for some OECD countries that are also members of the EU. The missing countries are not included in the OECD average for this calculation.

Source: OECD (2011d and 2013d), Government at a Glance.

The large degree of state ownership in potentially competitive segments of the Polish economy threatens competitive neutrality between public procurement bidders. Although public procurement rules are the same for private and public companies (special provisions apply to in-house procurement under some special circumstances defined by the European Commission's jurisprudence (OECD, 2012a) and the gas, water and electricity sectors), governments may be tempted to favour state-owned firms during bidding processes. These anti-competitive pressures may be particularly intense in sectors dominated by 
local governments where personal relations may be more important. Though decentralised local governments may be better at eliciting people's preferences and providing population-specific services than is central government, local public resources may easily be captured by local elites and politically powerful groups. In Poland, sub-central governments have often tried to shield local SOEs from competition. For example, municipalities have sought to prevent entry by funeral services companies in municipal cemeteries, and in many cases there is little competition for local water services and public transportation (OECD, 2009a). Similarly, municipalities have been shown to protect local monopolies in waste collection markets by requiring the use of municipal waste-storage sites even if cheaper alternatives exist nearby. The law that transferred waste-management responsibilities to local governments in June 2013, requiring them to establish public procurement processes, also implies a need to build sufficient public procurement capacities at the local level. Alternatively, local governments could set up a joint public agency in charge of waste management contracts to achieve scale economies in human resources and ensure fair competition in the bidding processes.

There is a heavy reliance on price for awarding public contracts in Poland: the lowest bid is almost always chosen. In about $90 \%$ of the awarded contracts in 2011, price was the only contract award criterion (Public Procurement Office, 2012). The main explanation is that civil servants are afraid of being accused of corruption. For simple tasks, the price of an offer may be the most important factor for decision makers. But for more complicated projects, technical details and methodologies, timing, execution, organisation, guarantees and references should also be taken into account both in contract specifications and the assessments of offers. In particular, environmental impact should be explicitly considered. Since the public sector is a major buyer of a wide range of products, its purchases can promote technological developments that enhance output quality, public health and ultimately citizen well-being (OECD, 2011c). By contrast, the excessive reliance on the lowest bidders could generate unfair competition, lower quality and increase the risks of leaving projects unfinished if contractors go bankrupt. A well known case is COVEC, a Chinese company, which was supposed to build a stretch of the A2 highway but which pulled out because the final costs would have been twice the amount of its initial offer.

Overall, contracting authorities should seek to build up capacities to better judge technical aspects of offers. For particularly complex projects, developing competitive dialogues, used for instance in the United Kingdom, could help civil servants appreciate technical details. In such procedures, competitors interact with each other on the specification in an open way, and bid prices relate to very similar specifications. A more stable public procurement framework would also help reduce uncertainty and lower bidding costs (OECD, 2013e). Better information during public tenders, focusing specifications on functional performance and appropriate sanctions for anti-competitive behaviour, could improve fairness, transparency and value for money in public procurement (OECD, 2009b). According to the amended Public Procurement Law proposed by the Public Procurement Office in August 2013, bidders in public tenders offering exceptionally low prices would be requested to provide evidence in support of the possibility of successful completion of the contract within the specified cost limit (Polish News Bulletin, 2013c). The proposed amendment also specifies dissuasive sanctions in case of infringements. Bidders may be excluded from future tenders and have their bid bonds retained by the ordering party if no satisfactory evidence is provided.

\section{Heterogeneous progress across sectors}

Polish regulatory policies for private service sectors vary in scope. First, network industries are characterised by natural monopoly segments, into which competition is difficult (or even impossible) to introduce. In such cases, the regulatory framework should be directed to securing non-discriminatory third-party access to the networks and opening potentially competitive segments to competition. Second, some sectors, such as professional services, retail distribution, financial services and agriculture, are inherently competitive, but the intensity of competition appears affected by distortionary regulations and 
the extent of state ownership. For example, self-regulation by professional service associations tends to strengthen incumbents' positions. Some regulations also favour local monopolies in the retail sector and reduce entry and exit in agriculture. Last, state ownership in financial services may also reduce competitive pressures.

\section{Competition remains weak in most network industries}

In network industries such as electricity and gas, if a company owning and managing the natural monopoly segment of the sector (the transmission and distribution systems) is also present in the potentially competitive part (production and supply), it may be tempted to shelter its activities in the competitive segment by barring or complicating access for (potential) competitors to the natural monopoly infrastructure segment. Therefore, separating vertically integrated utilities into different entities for the network infrastructure and competitive parts may enhance third-party access. Such a separation can take the form of accounting separation within the same company, legal and functional separation when the company is split into two legal, functionally unbundled entities under the supervision of the same owner, or ownership separation. Ownership separation tends to wipe out any bias of the infrastructure owner and operator in terms of third-party access. Though it is often claimed that vertical separation may result in under-investment in physical infrastructure, a vertically integrated firm can also engage in strategic under-investment to keep out new entrants from its competitive segments. Therefore, increasing competition in the competitive segments triggered by vertical separation is likely to generate significant investments by new entrants (OECD, 2012b). Indeed, empirical evidence for OECD countries suggests that incentive regulation in the natural monopoly segment coupled with an independent sector regulator increases investment (Égert, 2009).

\section{State-ownership distorts competition in the electricity and gas sectors}

Vertical separation started in Poland's gas and electricity sectors in 2004 under the influence of EU regulations. The first steps to open up the wholesale gas market to competition were taken that year when the gas transmission network system operator, Gaz-System, was carved out from the state-controlled historical operator, PGNiG. The Treasury has a controlling stake in both companies, but a third-party access rule to the network was introduced. The amendment to the Energy Law of September 2013 contains a further improvement. The transmission system operator is now supervised by the Ministry of Economy, while PGNiG remains under the control of the Ministry of Treasury. However, the two Ministries remain ultimately under the supervision of the Prime Minister. The legal and functional unbundling of gas distributors occurred in 2007 when six regional distribution system operators were created in the PGNiG group (OECD, 2012b). In 2013, these six system operators were consolidated into one distribution operator, which remains separated from the gas supplier (PGNiG S.A.) in the PGNiG group.

The liberalisation of the gas market is ongoing. However, despite legal and functional unbundling, improved third-party access and increasing interconnection capacities to neighbouring countries, PGNiG still controlled $95 \%$ of the gas sector in 2012, including production, imports, storage, wholesale and retail sales, and distribution (ERO, 2012). At the end of 2012, a gas exchange was created, and 97 entities were entitled to trade. The government introduced obligations for PGNiG and other important gas trading companies to sell $30 \%, 40 \%$ and $55 \%$ of the gas entering the Polish network on the exchange in 2013, 2014 and 2015, respectively. In July 2013, an amendment to the Energy Law also eased the entry of small distribution companies by giving them the right not to unbundle their supply and distribution activities as long as they do not distort competition. While these new developments go in the right direction and should ensure more transparent rules of trading in natural gas, there is room for further increasing competition. The current low share of alternative gas suppliers implies that third-party access is not working well, and it is unclear to what extent the creation of a gas exchange will increase competition, given PGNiG's dominant position. Indeed, the Competition Authority recently found that PGNiG has been applying 
contractual terms and conditions that are disadvantageous for entrepreneurs making wholesale or retail purchases of natural gas (UOKIK, 2014). The government should consider encouraging more entry into gas production and distribution, potentially by fully separating the ownership of: $i$ ) gas production from transmission, because both activities are owned by SOEs; ii) gas production and wholesale sales from distribution; and iii) distribution system operators from gas suppliers. Full ownership separation, which would involve the privatisation of the gas-supplying part of PGNiG, would ease the entry of new firms and limit possible political interference via the sector regulator.

Electricity production is also dominated by a few, mostly state-owned utilities. The largest majority state-owned electricity producer, PGE, generates almost $40 \%$ of Poland's electricity, and the top four generators account for almost $70 \%$ (ERO, 2013); three of those are directly controlled by the government. A power exchange for electricity producers was set up in 2010 and a legal obligation introduced for producers to sell at least $15 \%$ of their production on the exchange. At the same time, producers entitled to receive compensation covering their stranded costs under long-term power purchase agreements were obliged to sell all generated electricity on the exchange. The electricity transmission system operator, PSE, is legally unbundled from the large state-owned producers but is also $100 \%$ state owned. As in the gas sector, in September 2013, the government shifted the control of PSE from the Treasury to the Ministry of Economy, while the Treasury remains in charge of generators. Though this is encouraging, full ownership separation should remain an objective, and the Competition Authority should be given the power to reduce dominant market positions in case of competition infringements.

The Treasury is a major shareholder in four of the five main electricity distributors. These four capital groups are indirectly government owned and vertically integrated by ownership with major generators. They are also heavily involved in supplying businesses and households. The sector regulator reckons this to be a regulatory challenge (ERO, 2012). Third-party access to the distribution grid, supervised and enforced by the Energy Regulatory Office (ERO), was strengthened in 2013, as it turned out that, while switching suppliers was simple on paper, some distributors and suppliers made it difficult by delaying the switching procedure, misinforming customers and threatening to suspend electricity supply if buyers did not sign up again (ERO, 2012). About $35 \%$ of electricity supplied through the five large distribution grids in 2012 was provided by alternative suppliers (mostly the other incumbents). Nevertheless, there is a natural potential bias for distribution system operators to favour suppliers belonging to the same holding company over alternative operators; only full ownership separation - implying the privatisation of the state-owned generators - would fully eliminate this potential bias.

The National Renewable Energy Action Plan sets a 2020 target of $15 \%$ for the share of renewable energies. However, renewable forms of electricity remain underdeveloped. Since 2005, mandatory quotas for power companies and a green certificate market have pushed many state-owned coal-fired power plants to co-fire with biomass, but the development of other technologies has been limited. A better pricing of externalities could make other renewables more competitive, but grid capacity and management would also need to improve. Planned extensions of the interconnection capacity with neighbouring countries would foster competition between renewables producers and facilitate balancing of demand and supply, which is particularly challenging with intermittent supply typical of wind- and solar-powered generation (OECD, 2012c).

The natural-monopoly parts of the sector (the transmission and distribution grids) need to be overseen by an independent sector regulator that would simulate a competitive environment via incentive regulation with a view to forcing the incumbent operator to reduce inefficiencies. In Poland, the sectoral regulator, ERO, sets the regulatory framework for the distributors and the transmission system operator. This includes an RPI-X price-setting formula for these companies imposed over a period of four years (2012-15), which is long enough for them to reap the benefits of efficiency improvements. Nevertheless, imposing tough efficiency targets may be a tricky task for the regulator, given that almost all 
operators are government controlled. Therefore, it is vital to strengthen its political independence. In September 2013, the open-ended contract of the ERO President was transformed into a five year fixed-term contract that can be renewed only once. Ideally, the contract should also be made non-renewable and prevent the President from immediately taking a position in the energy sector at the end of his/her mandate to avoid revolving-door opportunities.

\section{The liberalisation of the telecommunications market has increased competition}

Liberalisation of the telecommunications market is fairly advanced. As a result, the market is increasingly competitive, especially in mobile services. One important change was the reinforcement of the independence of the sector regulator (UKE), which came in 2009 after the European Commission opened proceedings against Poland. The UKE's President now has a five-year fixed-term contract, and the conditions for dismissal are also clearly spelled out, contrary to other sector regulators and the Competition Authority. The President cannot take up a job in the telecommunications industry during the year following departure from the UKE, a safeguard aimed at minimising conflicts of interest. UKE enforces telecommunication regulations by monitoring access charges using tests for predatory pricing (based on audited costs) and oversees how quickly customers can change providers. From 2006 to 2013, UKE made some 400 decisions regarding complaints over third-party access. However, UKE's decisions are frequently appealed before administrative and general courts, which make their implementation lengthy, and a mobile termination rates case triggered extraordinary action by the European Commission (European Commission, 2012c).

The sector also differs from other network industries due to its comparatively low level of government ownership. The incumbent firm, Telekomunikacja Polska (TPSA), was fully privatised in 2010. Switching barriers have been lowered in recent years, shown by the shorter time needed to change operators for fixed-line phones while keeping the same number ("portability") from 23 days in 2009 to an average of 7 days in 2013 (one day for the applications directly submitted by customers and 14 days for others). However, TPSA still dominates both landline telephones and, to a lesser extent, fixed-line broadband. A new entrant in the mobile market has recently boosted competition, lowering prices to levels considerably below the EU average, while mobile termination rates have been declining (OECD, 2012d).

Despite these competitive pressures, the telecommunications sector still faces some important challenges. First, TPSA's privatisation also suspended the separation of its wholesale and retail activities. Given TPSA's record of delaying tactics regarding third-party access, this still requires close vigilance by UKE. Notwithstanding the 2009 agreement between UKE and TPSA on third-party access to the physical infrastructure, in 2011 the European Commission fined TPSA for abusing its dominant market position in broadband. Indeed, TPSA "proposed unreasonable conditions, delayed the negotiation processes, rejected orders in an unjustifiable manner and refused to provide reliable and accurate information to alternative operators" (OECD, 2012b, p. 81).

Second, the fixed-line network remains underdeveloped and outdated. Landline telephony is fairly limited, and prices are above the OECD average for most bundles (OECD, 2013f). In 2011 the number of telephone lines per capita was among the OECD's lowest (Figure 10, Panel A). In addition to TPSA, other SOEs own and operate backbone infrastructure (TK Telekom - owned by public railway and power companies - and Exatel, controlled by the state-owned gas firm). Mobile and internet use has been growing rapidly in recent years but is reliant on upgraded backhaul networks to provide broadband connectivity services. The backbone infrastructure is patchy, and extending the network may be costly, especially in rural areas with low population density. Delivering a well functioning broadband network, using either fixed or mobile wireless networks requires the roll out of these networks into these areas. If rolling out fixed broadband in the last mile is deemed to be expensive, expanding wireless networks may be appropriate. However, this still requires the fibre backbone to be rolled out to the antenna sites. 
Figure 10. Fixed-line infrastructure is underdeveloped

2011 or latest year available

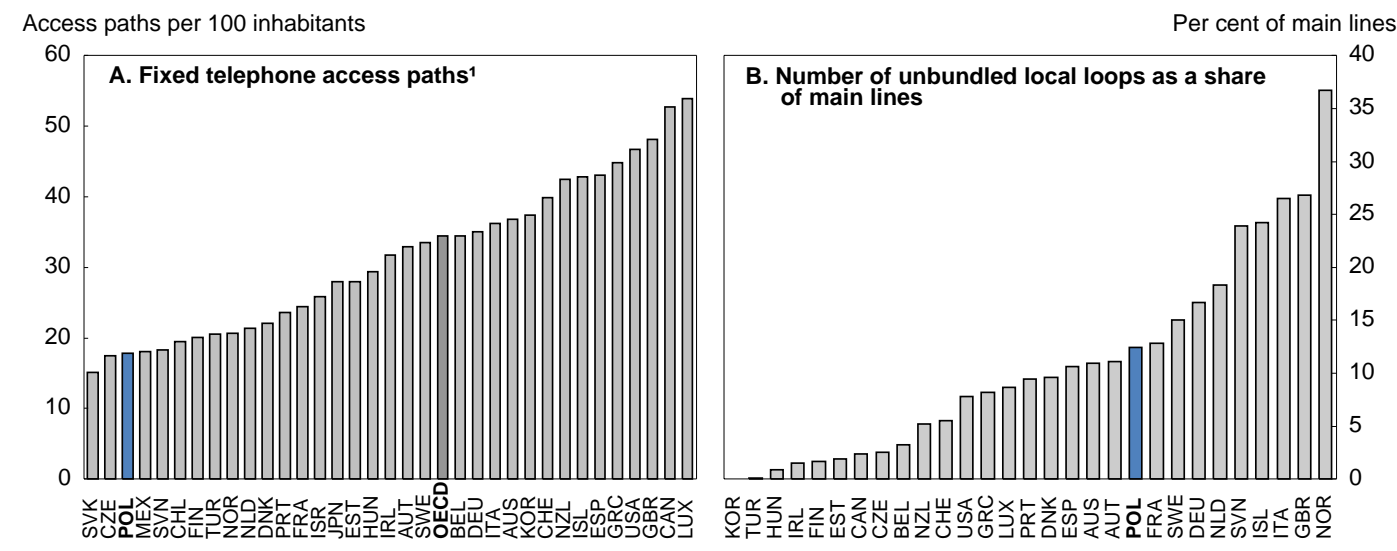

1. Fixed telephone access paths include analogue and ISDN lines.

Source: OECD (2013f), Communications Outlook 2013 (Panel A) and OECD (2011d and 2013f) Communications Outlooks 2011 and 2013 (Panel B).

Third, the underdevelopment of the fixed-line network may create competition problems at the local level for Internet service providers, where there could be limited choice for consumers. Local loop unbundling (LLU) may not yet be fully functional, in view of the concerns about third-party access raised by the European Commission in 2011 (OECD, 2012b). Progress in LLU has been fast but from a low level (Figure 10, Panel B): the share of unbundled local loops in total main lines increased from 5.3\% in 2009 to $12.4 \%$ in 2011, and substantial investment would be needed for further upgrading (OECD, 2011d and 2013f).

Finally, the low Internet and broadband penetration rates can impede the rapid distribution of ideas and information and act as a drag on competition and economic growth (OECD, 2011e). The number of households with Internet connections is low in international comparison (at some 72\% in 2013), in sharp contrast with almost $100 \%$ in Korea (Figure 11). Furthermore, Poland is the second-worst OECD performer in terms of business access to broadband. More than $20 \%$ of firms with 10 or more employees still did not have broadband connections in 2011.

Figure 11. Internet access is still low by international standards

Broadband connections, 2011 or latest available year
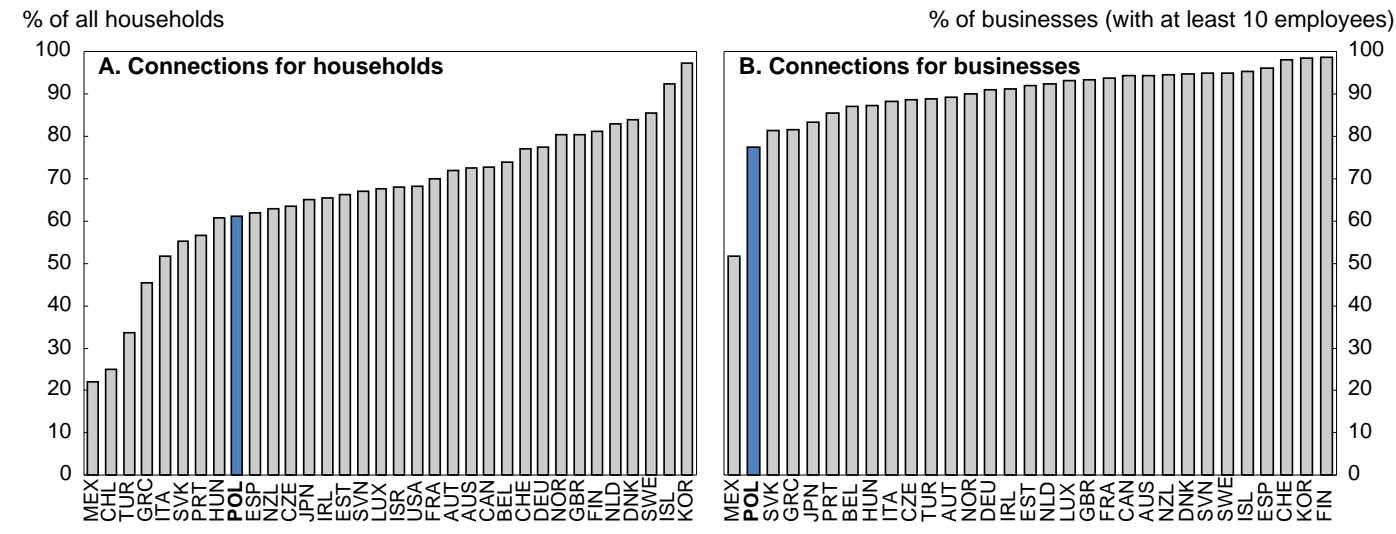

Source: OECD Key ICT indicators, 2012. 


\section{Postal services are being liberalised}

Domestic postal services have been progressively liberalised in Poland since 2006 for parcel delivery and partly for letters. The incumbent operator, Polish Post, is considered highly inefficient (Cienski, 2013), implying that increased competition would generate large productivity gains and lower prices. In November 2012, the new Postal Law designated Polish Post as a universal service provider for a transitional period of three years to fulfil the requirements of the 2008 EU Postal Directive, and the market for letters less than 50 grams in weight was opened to alternative providers in January 2013. After the three-year transition period, a new national operator will be selected for 10 years through a competition organised by the sector regulator (UKE). Potential bidders at the tender to be held in 2016 are complaining that the requirement of having a national postal infrastructure is very difficult to meet within three years and that the incumbent enjoys a considerable advantage from the start. Other sources of unfair competition are the fact that the incumbent operator may be able to keep its privileged position for postal money orders and that the definition of mass sender in the law provides VAT exemption for universal postal services that are currently provided by Polish Post. Finally, only proof of registered letters posted at a post office is considered as official, and alternative service providers do not have full third-party access to the incumbent's postal infrastructure (Integer, 2012; WIK-Consult, 2013).

\section{The water industry should be supervised by a nation-wide regulator}

The water sector is dominated by municipally owned water and wastewater utilities, which are mostly not corporatised. Out of the 50 largest companies, only one is not majority-owned by local governments (Saur Group in Gdansk, controlled by a French state-owned firm). The water industry landscape is very fragmented: there are about 1600 water companies, compared with slightly fewer than 2500 municipalities. There is no national sectoral regulator, and the mayor of each municipality is in charge of supervising the local water company. Water companies propose tariffs, which have to be approved by municipal councils. Overall, it seems that they are not very efficient, as they suffer from overstaffing, a lack of automation and low wages (OECD, 2011e), and, in 2008, water and sanitation bills as a share of disposable income were the highest among the 22 OECD countries surveyed (OECD, 2010c).

The creation of an independent national sector regulator could help increase efficiency. In the recent past the Competition Authority has had to handle a number of cases of abusive contract clauses faced by small businesses and consumers. A national regulator could set some sector-wide standards for invoicing and other procedures relating to suppliers' monopolistic positions. It could set productivity targets for each company using international benchmarking and yardstick regulation, which would simulate a competitive environment. Such regulation could push water companies to merge to reap the benefits of scale economies. Waste water collection and treatment services could also be included under the responsibilities of this national water regulator. More efficient operations could leave more room to finance badly needed investment in the water supply and sewage infrastructure. Poland is one of the few OECD countries where a non-trivial share of the population, $13 \%$, was not connected to water supplies in 2009. Also, compliance with EU regulations in terms of water sanitation implies a need for substantial investment.

\section{Competition in railways remains limited}

Increasing competition in the rail sector is likely to link prices more closely to service quality, which might help to enhance intermodal competition, increase the share of rail in overall traffic and lower greenhouse gas emissions and air pollution. The special chapter on transport and infrastructure in the 2008 Survey suggested that the Polish rail sector was very inefficient (OECD, 2008a; Kierzenkowski, 2008). Although some progress has been made, the quality of railroad infrastructure is still perceived by world executives to be the worst in the OECD (World Economic Forum, 2013). Several restructuring programmes have been carried out to improve the efficiency of the state railway company (PKP). It was 
split into a holding company, owning freight, national and regional passenger transportation and infrastructure-management entities. In 2007 the government launched a strategic plan called "Strategy for railway transport until 2013". At the heart of the programme was the preparation of the cargo and transnational passenger parts of PKP for privatisation. While the cargo part of the company (PKP Cargo) was partly privatised in October 2013, the government still controls a majority of its shares, and the privatisation of the passenger part (PKP Intercity) has not yet started.

SOEs dominate the passenger transportation segment through PKP Intercity and a number of regional operators. The five largest operators accounted for more than $90 \%$ of the market in terms of passengers in 2011 (UTK, 2012). Only one company is not controlled by the state or local governments - Arriva RP, belonging to Deutsche Bahn, which has a market share of $1 \%$. More competition could be expected to result in substantial productivity gains. The 2008 Survey (OECD, 2008a) suggested that competition could be encouraged via competitive bidding for the provision of services in specific regions. But it is also important that the organisation of passenger transport on a regional basis does not lead to anti-competitive behaviour by operators restricting inter-regional traffic.

The liberalisation of rail freight transportation started in 2003, and a large number of licenses were soon issued by the sector regulator (UTK) for both freight transport and rolling stock leasing. Accordingly, the prices of rail freight services have declined sharply, new services have been developed, and the market share of the incumbent (PKP Cargo) has fallen. Yet, in 2012 PKP Cargo still had a market share of $60 \%$ (down from 80\% in 2006), and other SOEs, including PKP LHS, which is specialised in heavy industry, and Lotos Kolej, transporting the products of the state-owned oil company Lotos, played an important but declining role in the freight market. The fact that the management of the rail infrastructure is dominated by the state-owned company PKP PLK S.A., part of the PKP group, is a serious impediment to competition. Indeed, PKP Cargo had a privileged position regarding the allotment of routes by PKP PLK S.A. (OECD, 2008a). Moreover, 6 out of the 28 operating trans-shipment terminals (including the most important one - Malaszewicze - at the Eastern border) are owned by PKP Cargo or its subsidiary, Cargosped Sp. z o.o. The 2008 Survey recommended vertical separation, preferably based on ownership, rather than legal or accounting separation, of the main state-owned infrastructure manager (PKP PLK S.A.) from the PKP Group, which would help increase competitive neutrality between the public and alternative carriers and improve the transparency of access pricing by eliminating the possibility of cross-subsidies within the PKP Group.

The independence of UTK could be improved. As in other network industries with strong public ownership, the President of UTK is appointed for an indefinite period and can be recalled by the Prime Minister at his own discretion (Krol, 2010). In fact, the Prime Minister used his prerogative in 2012 and dismissed the last UTK's President. Enhanced political independence could be insured through a fixed-term non-renewable mandate defining clear dismissal conditions, coupled with the vertical separation of the infrastructure manager from the state carrier. This would help guarantee third-party access to the network, including non-discriminatory access pricing. Indeed, UTK may have tended to approve prices put forward by the infrastructure manager, PKP PLK S.A., with little discussion (OECD, 2008a), resulting in inflated charges that have led to significant claims by rail network users. In May 2013, the EU Court of Justice found that charges for accessing the infrastructure were excessive (Court of Justice of the European Union, 2013). Recently, UTK has displayed more scrutiny about proposed access charges: in April 2013 it refused to approve the access charges initially proposed by PKP PLK S.A. until some significant amendments were made.

\section{State-ownership is important in aviation and seaports}

Poland has 13 airports. The stakeholders are the Polish Airports' State Enterprise (PPL) (supervised by the Ministry of Infrastructure and Development), municipalities and regions. Warsaw and Zielona Góra 
airports are managed by PPL, and the other 11 airports run their businesses as separated commercial law companies, though PPL still owns substantial shares in many of them. This ownership structure is not conducive to competition among airports. A solution would be to fully insure the independence of the infrastructure manager from the airport operators to allow more competitive and transparent pricing policies. Airport owners could issue long-term concession agreements for different airports. The key, of course, is that the auctions and concessions be properly designed and executed to prevent collusion and attract entry, while avoiding opportunistic renegotiations and providing sufficient incentives for long-term investments (OECD, 2007). The government currently aims to corporatise PPL to increase its efficiency and financing opportunities. This could be a first step towards privatisation, as recommended in the 2008 Survey.

Polish airports have some degree of regional monopoly power, but their overlapping catchment areas and the high share of low-cost airlines, which shift easily between airports, put downward pressure on airport charges. Since January 2014, the Civil Aviation Authority (CAA) monitors airport charges based on forecasted costs. CAA is relatively independent as the rights and duties of its President are defined in Aviation Law Act. Its President has an open-ended contract and is appointed by the Prime Minister. Though the recruitment process is open and competitive, awarding CAA's President a fixed-term non-renewable contract ensuring that he or she cannot be dismissed without fault would guarantee further independence. For airports above 5 million passengers, CAA can accept or reject charges proposed by airport managers, while for smaller airports it can require modification of the established charges. However, it can do so only based on whether the procedures followed the legal fee-setting framework but cannot verify economically the costs behind the fee proposals (Wolszczak, 2009). Allowing the regulator to verify the economic costs covered by airport fees would likely increase competitive pressures.

Air transport has been developing at a rapid pace, as domestic and international flights were liberalised following Poland's EU accession and the entry of a number of low-cost airlines. Yet, the state-owned airline company (LOT) has a $28 \%$ market share in terms of passengers transported (similar to Ryanair's but above Wizz Air's 20\%, according to Warsaw Business Journal, 2013). The government has made several failed attempts to privatise LOT. It needs urgent restructuring, having incurred losses for a number of years, requiring public subsidies, currently under investigation by the European Commission. A large, subsidised state-owned airline and the presence of state-owned airports may challenge competitive neutrality. Though Polish Aviation Law ensures some independence of landing slot allocation from airport owners and airlines, state-owned airports may be tempted to shelter LOT from its competitors through access prices.

According to the World Economic Forum (2013), the quality of Poland's seaport infrastructure is perceived as poor, ranking $97^{\text {th }}$ out of 148 countries. One reason for this is that the major seaports are state-owned and poorly managed. But they have started upgrading their outdated capital stock, as advocated in the 2008 Survey. While they are still in public hands, private investors have created companies operating in existing ports, contributing to their revival. At the same time, geographically close ports, such as Gdansk and Gdynia, have started competing with each other. More widespread privatisation could further enhance competition and efficiency. However, ports enjoy favourable tax treatment, which may distort intermodal competition, and such tax breaks should be phased out (OECD, 2008a).

\section{Professional services have been partly deregulated}

Self-regulation (or similar rules embodied in legal statutes) in professional services is relatively common in OECD countries, but it may restrict competition unnecessarily. Indeed, Poland had about 350 regulated professions in 2011 (Rojek, 2013). Its average level of regulation of finance and legal professionals and for architects and engineers was above the OECD average in 2013 and substantially above the lowest levels observed in countries such as Finland, Sweden or the United Kingdom (Figure 12). 
Low-level indicators show that heavy regulation mostly took the form of strict entry barriers (licencing and education requirements), whereas conduct regulations are lax. This indicates that lighter entry regulations would probably foster competition, without being detrimental to the quality of services.

Figure 12. The OECD's indicator of the severity of professional services regulation in $2013^{1}$ Index scale from 0 to 6 , from least to most restrictive

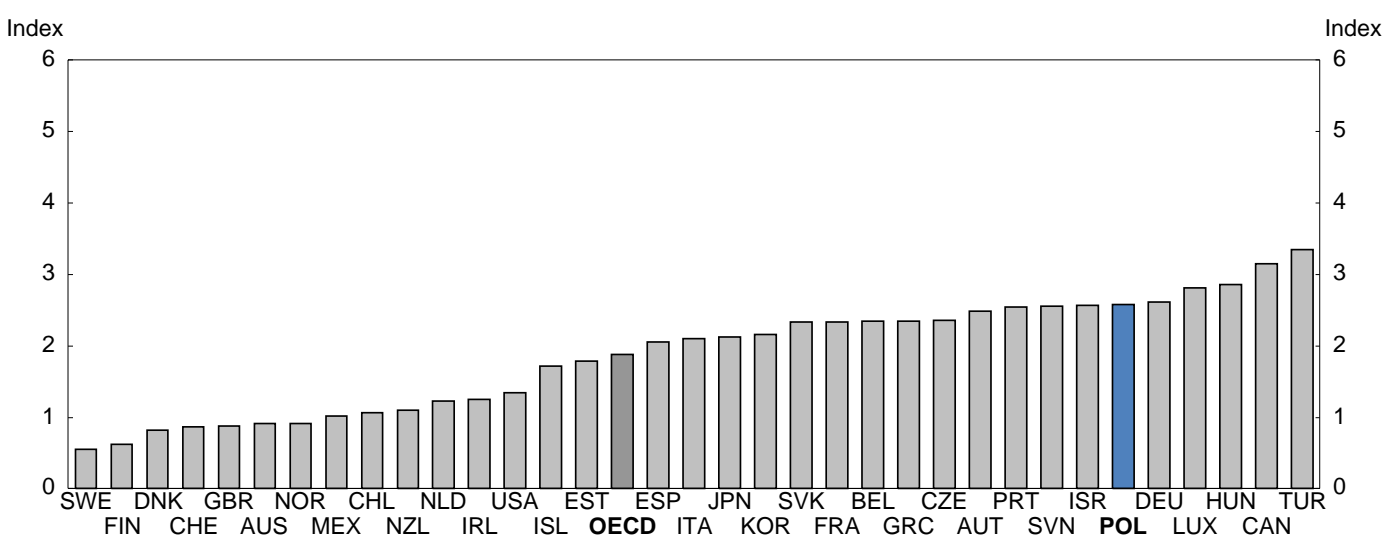

1. 2008 for the United States.

Source: OECD (2014), preliminary Product Market Regulation database.

Against this background, the government recently launched a large deregulation programme. In 2011, about $70 \%$ of the currently regulated professions were identified for full or partial deregulation. While this would align Poland only with the EU average, it would still be a very important step towards reducing entry barriers and exposing those occupations to more competition. It is likely to reduce prices and thus monopoly rents and create additional jobs in the economy, especially for young people. Productivity will probably rise in the deregulated professions, and reduced red tape and lower input costs would also increase competitiveness in other sectors using these professional services.

The deregulation programme concerns some 250 professions accounting for $6 \%$ of the labour force (about 1 million people), including 3\% of the labour force in the sectors subject to complete deregulation. It will be conducted in three waves. The first, adopted by the Parliament in June 2013, comprises 51 professions, notably legal professions. It aimed to speed up and lighten entry examinations and to extend eligibility for attorneys and bailiffs, scrap the nationality requirements for notaries, phase out the university degree requirement for court and prosecutor staff, real estate brokers and managers and driving instructors, and shorten the duration of the compulsory apprenticeship for a number of professions. Although professional interest groups are opposed to deregulation and argue that it may go too far and will reduce quality, there is general public backing for it, as shown in recent opinion polls and by the approval of the first bill by both government and opposition Members of Parliament (Rojek, 2013).

The second wave of deregulation launched in the second half of 2013, is aimed at 91 professions. It is expected to be passed in the first half of 2014. The professions concerned include engineers in various sectors, accountants and tax advisors, car diagnostic technicians, commercial pilots, railway professionals and insurance brokers. For example, special examinations will no longer be necessary to become a stockbroker for those who hold an appropriate degree and have at least three years of experience with a stockbroking firm (Polish News Bulletin, 2013a). Some double examinations in selected professions will also be eliminated. A university degree would henceforth be enough to enter these professions; the related profession-specific exams, which overlap to some degree with what is taught in the education system, will be eliminated. 
The third wave was also launched in 2013, a public inter-ministerial consultation was carried out in the summer, and the draft act was accepted by the Permanent Committee of the Council of Ministers in December 2013. The deregulations would concern more than 100 remaining occupations, mostly in finance, mining and some crafts. Further professions, including medical professions and jobs concerned with safety at work, may be added to the list. This may eventually lead to a fourth wave of deregulation.

This impressive programme will be accompanied by an ex post impact assessment of the deregulation process for the most important cases, which will examine its effects on prices, incomes and employment. The results may trigger corrective measures with regard to access conditions. Indeed, a careful balance needs to be struck between easing access requirements and maintaining quality, and ex post evaluations will help to assess whether it has been. On the one hand, there is a risk that unnecessary regulations will remain in place; on the other, some regulations may indeed lead to higher quality.

The government also intends to further reduce the extent of double examinations in some professions, conditional on the ongoing restructuring of the tertiary education system. In concert with the ongoing deregulation of professions, two further changes are being considered by the government. First, it would like to ensure that implementing EU directives in Poland will not be coupled with additional regulations at the national level. The second concerns the review of professional self-governing bodies required by law. For example, as a result of the review of the obligatory professional chamber of city planners, the government proposed the liquidation of this chamber in the second wave of deregulation.

\section{Competitive pressures appear low in retail trade}

Even though regulation in retail distribution was reduced to some extent between 1996 and 2008, Poland stood out in 2008 as one of the OECD countries with the most stringent regulation in this sector (Figure 13, Panel A). Disaggregated indicators show that licencing requirements are extremely burdensome, with little change over time (Panel B). Regulations concerning large outlets have been eased to some extent over time, and the protection of existing firms has remained stable at moderately high levels. By contrast, the lenient regulation for shop-opening hours was toughened between 1996 and 2003: municipalities have the right to set limits on retail opening hours, but it is rare that they impose strict opening hours. Shops can open on Sundays. Nevertheless, since 2007, they must close on most national holidays, except fuel stations and small owner-operated outlets. Large stores are allowed to have month-long sales twice a year at the end of the summer and winter seasons. However, large retailers can reduce prices if this is economically reasonable (e.g. due to high stocks) and if this is not meant to make access to market by smaller retailers more difficult. There are no restrictions regarding the extent of price reduction.

Despite the recent expansion of some of the major international retail groups and e-commerce in Poland, retail trade is to a large extent dominated by very small shops, which, in 2007 , contributed to almost half of the sector's total turnover, the third highest share after Italy and Greece (Figure 14). This suggests that current regulations protect local incumbents from new entry. The sector's structure is also reflected in high price-cost margins (Figure 4) and apparent limited efficiency gains: between 2004 and 2011 , average annual sectoral labour productivity growth was slightly above 1\%, while Bulgaria and Latvia reached gains of around $6 \%$ per annum. These developments suggest that reducing barriers to entry could foster further competition in the retail sector, though they may also be partly explained by the preference of Polish consumers for small shops. 
Figure 13. Regulation in retail distribution services

Index scale from 0 to 6 , from least to most restrictive
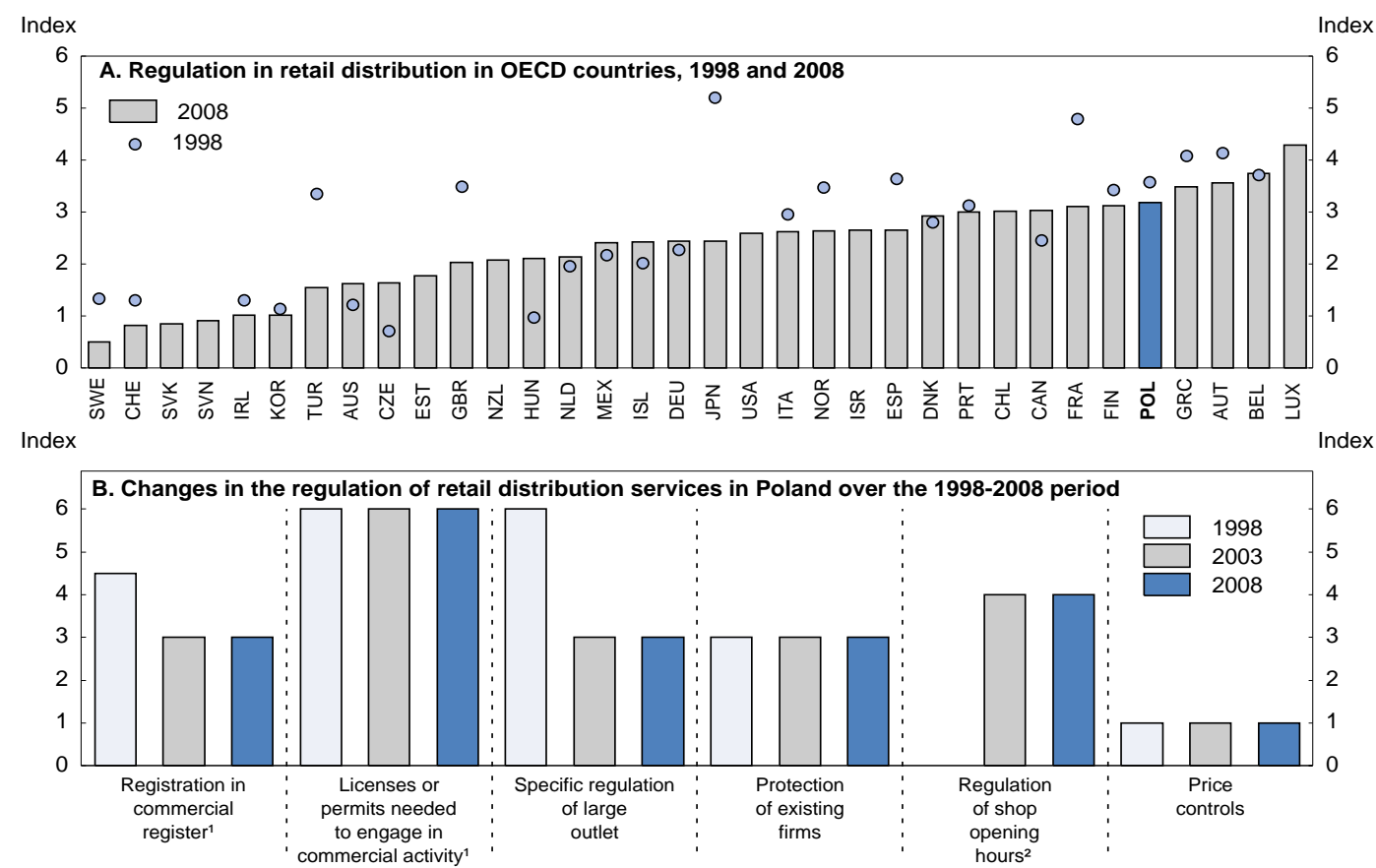

1. Refers to licenses and permits needed for food outlets.

2. The sub-indicator for regulation of shop opening hours was 0 in 1998.

Source: Update of Conway et al. (2006), "Regulation, Competition and Productivity Convergence", OECD Economics Department Working Papers, No. 509, OECD publishing.

Figure 14. The wholesale and retail trade sectors

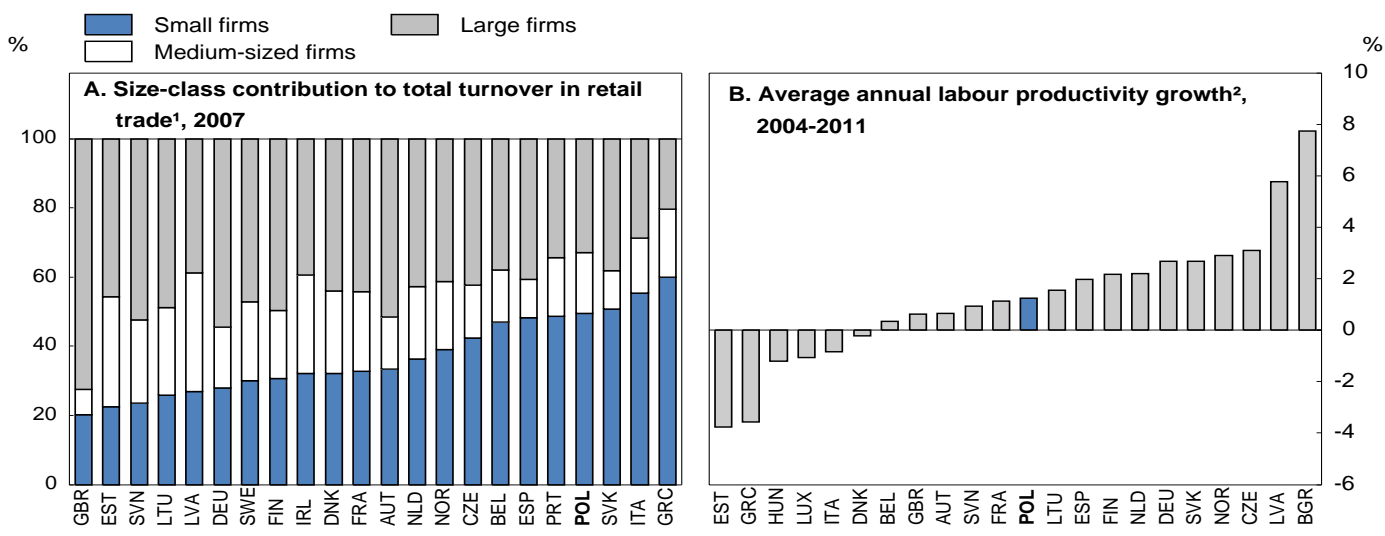

1. Small firms are those with 1 to 19 employees, medium-sized firms between 20 and 249 and large firms 250 and more.

2. Labour productivity is computed as follows: gross value added in constant prices divided by total employment in wholesale and retail trade, repair of motor vehicles and motorcycles. Data are drawn from a 10-sector decomposition.

Source: OECD's Structural Business Statistics Database for Panel A; OECD calculations based on data from Eurostat's national accounts database for Panel B.

\section{The agricultural sector is very fragmented}

The agricultural sector appears fragmented and leaves little scope for contract-based employment. In 2010, average farm acreage was still only half the EA15 average (Figure 15, Panel A). Farms with less 
than 20 hectares represented $92 \%$ of the holdings and $85 \%$ of agricultural employment, but only $55 \%$ of total farm output (Eurostat, 2010). At the same time, the share of agricultural workers in 2012 who were self-employed, 95\%, was much higher than in the EA15 or the rest of CEEC4 and has been stable since 1998 (Figure 15, Panel B). Among comparator countries, only Slovenia displays a similar share of self-employed farm workers, albeit declining.

Figure 15. Competition distortions contribute to a heavily fragmented agricultural sector
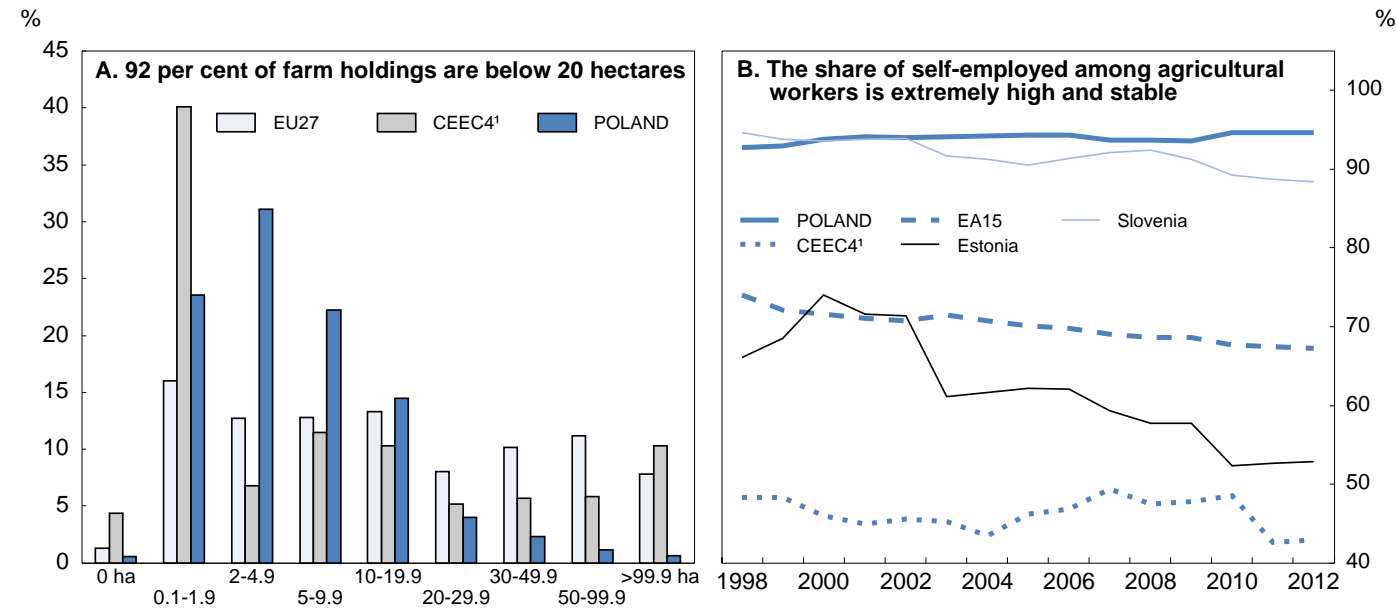

1. In both panels, CEEC4 is the unweighted average of Hungary and the Czech and Slovak Republics.

Source: Eurostat farm structure survey 2010 (Panel A) and Eurostat Agriculture Labour Input Statistics 2012 (Panel B).

Some subsidies to the agricultural sector constrain an efficient consolidation of the sector and distort competition among farmers. Farm support through the Common Agricultural Policy weakens the incentives to leave the sector, and an advantageous social security system, the KRUS, as well as specific tax expenditures provide additional subsidies to individual farmers and their dependants (OECD, 2008c and 2011f). The significant difference in contribution rates - for pensions and social security - combined with similar benefits encourages individual workers to hold on to small plots of land to ensure eligibility for KRUS, despite their extremely low productivity (OECD, 2004 and 2006; Tompson, 2009). By contrast, farmers employing agricultural workers, co-operatives and corporate farms have to insure their workers in the state welfare system, ZUS, and pay higher contributions for their employees' pensions than those of individual farmers (European Commission, 2003). Furthermore, since 2009, the level of pension contributions of Polish individual farmers to the KRUS has been dependent on farm size, but higher contributions do not lead to higher benefits, creating further distortions between farms of different sizes.

Specific tax expenditures also slow the consolidation of the agricultural sector and reduce competition between individual farm holdings and farm companies by increasing the cost of entry. Individual farmers are exempt from personal income tax and are liable instead for an agricultural tax. The calculation of that tax depends on farm area, the type of arable land, the class and the location of the farm. However, agricultural company shareholders are taxed in the same way as non-agricultural companies. The current government had planned to harmonise farmers' social contribution and taxation on the general system (Tusk, 2012). However, implementation has so far been lagging, though small health-care contributions for KRUS beneficiaries were introduced in 2012. Indeed, health insurance for individual farmers with less than six hectares of land (around $60 \%$ of all farms) remains totally covered by the state budget. 
ECO/WKP(2014)21

\section{Financial services are generally competitive}

Financial services seem generally competitive in Poland, and any increase in competition among financial institutions should be weighed against the increased potential risk of financial and macroeconomic instability (OECD, 2011g; Ratnovski, 2013). The Treasury continues to control the largest commercial bank and two others, representing around one fifth of the total assets of the banking sector, in addition to the state investment bank, BGK. Foreign financial institutions owned 37 banks and 19 branches of credit institutions, which together held $65 \%$ of the sector's total assets. The foreign ownership structure appears relatively diversified according to country of origin of the primary dominant entities: Italy, Germany, the Netherlands and Spain owning comparable shares. The six private banks with majority Polish ownership accounted for $6.7 \%$ and the 572 co-operative banks for $6.1 \%$ of total assets. The position of the 10 largest banks has a crucial impact on the sector as a whole - at the end of 2011 their assets accounted for $62.1 \%$ of the total banking assets, but sectoral proxies for competitive conditions, such as price-cost margins, net interest margins, and indices of concentration, generally tend to show an increasingly competitive environment (Pawlowska, 2012). The Financial Supervision Authority (KNF) supervises the banking, insurance, pension fund and securities sectors, and oversees payment institutions. It is also responsible for competition (as a means of achieving financial stability), conduct of business and development issues, while the Competition Authority is in charge of competition and consumer protection. The KNF has been praised for its governance and independence (Kowalski and Rybinski, 2011).

Though competitive pressures appear significant, state ownership may threaten competitive neutrality among financial institutions, and, given the inherently competitive nature of retail banking, the government should consider fully privatising state-owned commercial banks over the medium term. Furthermore, Polish co-operative banks, which are particularly important for the agricultural sector, appear operationally less efficient than commercial banks (IMF, 2013b). This may result from the fact that voting rules are independent of the number of shares an individual member holds, which reduces the probability of take-over of inefficient institutions. Co-operative banks may also reduce local competitive pressures in retail banking. Indeed, three elements can potentially increase their market power: $i$ ) regulations may discriminate in favour of co-operative banks; $i$ ) network co-operation practices may restrict competition; and iii) connections with local politicians may create entry barriers (European Commission, 2007; Fonteyne, 2007). However, in the medium term competition from commercial banks is likely to increase, as they are beginning to encroach on co-operative banks' traditional small-town and rural territory.

Interbank fees for card transactions are very high in Poland, suggesting competition issues (Figure 16, Panel A). Indeed, the two main firms, Visa and MasterCard, control 99\% of the Polish market, as in many other European countries (European Commission, 2013). The high prices caused by interchange fees are harmful to consumers, who tend to be unaware of the fees paid by merchants for such payment instruments. At the same time, a series of incentivising practices applied by providers (such as travel vouchers, bonuses, rebates, etc.) steer consumers towards the use of payment instruments generating high fees. Against this background, in 2006 the Polish Competition Authority issued a decision that agreements between banks on the level of interchange fees were in breach of competition law. However, the case is still in the courts. More recently, the Parliament decided to cap interchange fees at $0.5 \%$ of the transactions from July 2014. Polish regulations would interact with the recent European proposals, which would introduce a ceiling of $0.2 \%$ for debit card rates and $0.3 \%$ for credit cards on interchange fees (European Commission, 2013). Such a reduction in card fees is likely to lead to a higher acceptance and usage of cards in Poland (Panel B). 
Figure 16. Card fees are high by European standards, 2012
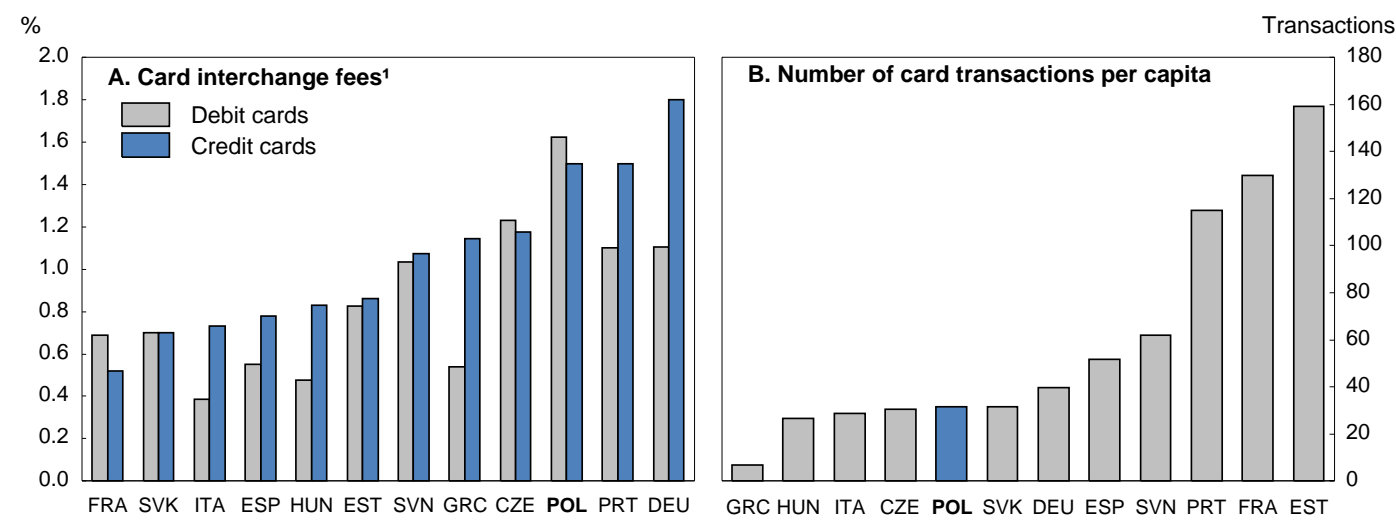

1. Average weighted domestic interchange fees from Visa and MasterCard for consumer cards.

Source: European Commission (Panel A) and European Central Bank (Panel B).

\section{Recommendations for invigorating product market competition}

\section{Barriers to entrepreneurship and state ownership}

- Lower further the costs of entry and exit, such as red tape. Reduce the length and costs of bankruptcy procedures.

- Pursue privatisation, and substantially reduce government ownership in competitive segments of the economy while ensuring sound governance of remaining state-owned enterprises. At a minimum, regulations and implicit subsidies distorting competition between public and private firms should be removed.

\section{Competition law and policy}

- Introduce fixed-term non-renewable mandates for the President of the Competition Authority and all sectoral regulators, during which they cannot be dismissed without fault, and prevent revolving-door opportunities.

- Give the Competition Authority more power including to split up companies so as to reduce dominant market positions and impose vertical separation as a remedy for third-party access problems in network industries.

- Accelerate the functioning of the judicial system to shorten the time between the Competition Authority's decisions and a final court decision in antitrust cases by, for example, developing the use of information and communication technologies.

- Modify public procurement practices to select contractors offering the best value for money rather than the lowest prices. Focus procurement decisions on a mix of prices and technical bid details. This will require enhancing staff skills to deal with complex selection criteria.

- Make the judicial environment friendlier to class actions in cases of competition breaches.

\section{Regulatory policies in network industries}

- Reduce further public ownership in competitive segments of the energy and water sectors.

- Create an independent sector regulator for water and sanitation services.

- Increase competition in rail transportation. Insure total independence of the main public infrastructure manager from the operators. Reduce anti-competitive pressures resulting from the participation of Polish Airports State Enterprise (PPL) in many airport entities, and consider long-term concession agreements or privatisation for airport entities. Privatise the national air carrier (LOT).

\section{Regulatory policies in competitive industries}

- Fully implement the second and third stages of the liberalisation of professional services.

- Substantially reduce the current level of government subsidies to individual farmers compared to farm companies. Progressively align farmers' social security contributions and personal income tax on the general system.

- Set a cap on interbank fees for credit card transactions to reduce the effects of market concentration in line with the $2013 \mathrm{EU}$ proposal. 


\section{Bibliography}

Acemoglu, D., P. Aghion and F. Zilibotti (2006), "Distance to Frontier, Selection and Economic Growth", Journal of the European Economic Association, Vol. 4, No. 5, pp. 37-74.

Aghion, P., N. Bloom, R. Blundell, R. Griffith and P. Howitt (2005), "Competition and Innovation: An Inverted-U Relationship”, Quarterly Journal of Economics, Vol. 120, No. 2, pp. 701-28.

Aghion, P., M. Dewatripont, L. Du, A. Harrison and P. Legros (2012), "Industrial Policy and Competition", NBER Working Papers, No. 18048.

Alemani, E., C. Klein, I. Koske, F. Vitale and I. Wanner (2013), "New indicators of competition law and policy in 2013 for OECD and non-OECD countries", OECD Economics Department Working Papers, No. 1104, OECD Publishing.

Alesina, A., S. Ardagna, G. Nicoletti and F. Schiantarelli (2005), "Regulation and Investment", Journal of the European Economic Association, Vol. 3, No. 4, pp. 791-825.

Bloom, N., C. Propper, S. Seiler and J. Van Reenen (2013), “The Impact of Competition on Management Quality: Evidence from Public Hospitals”, CEPR Discussion Papers, No. 9083.

Bouis, R. and R. Duval (2011), "Raising Potential Growth After the Crisis: A Quantitative Assessment of the Potential Gains from Various Structural Reforms in the OECD Area and Beyond", $O E C D$ Economics Department Working Papers, No. 835, OECD Publishing.

Boulhol, H. (2010), "Pro-competitive effect of trade and non-decreasing price-cost margins", Oxford Bulletin of Economics and Statistics, Vol. 72, No. 3, pp. 326-56.

Bourlès, R., G. Cette, J. Lopez, J. Mairesse and G. Nicoletti (2010), "Do Product Market Regulations in Upstream Sectors Curb Productivity Growth?: Panel Data Evidence for OECD Countries", OECD Economics Department Working Papers, No. 791, OECD Publishing.

Bravo-Biosca, A., C. Criscuolo and C. Menon (2013), "What Drives the Dynamics of Business Growth?", OECD Science, Technology and Industry Policy Papers, No. 1, OECD Publishing

Capobianco, A. and H. Christiansen (2011), "Competitive Neutrality and State-Owned Enterprises: Challenges and Policy Options”, OECD Corporate Governance Working Papers, No. 1, OECD Publishing.

Christiansen, H. (2011), "The size and composition of the SOE sector in OECD countries", OECD Corporate Governance Working Papers, No. 5, OECD Publishing.

Ciccone, A. and E. Papaioannou (2007), "Red Tape and Delayed Entry", Journal of the European Economic Association, Vol. 5, No. 2-3, pp. 444-58.

Cienski, J. (2013), "Polish post office set for a revival”, Financial Times, 11 January.

Court of Justice of the European Union (2013), "Poland failed to fulfil some of its obligations under EU law in the area of rail transport", Press Release, No. 64/13. 
Criscuolo, C., R. Martin, H. Overman and J. Van Reenen (2012), “The Causal Effects of an Industrial Policy", NBER Working Papers, No. 17842.

Djankov, S. (1999), "The restructuring of insider-dominated firms: A comparative analysis", Economics of Transition, Vol. 7, pp. 467-479.

Égert, B. (2009), "Infrastructure Investment in Network industries: The Role of Incentive Regulation and Regulatory Independence", OECD Economics Department Working Papers, No. 688, OECD Publishing.

Égert, B and R. Kierzenkowski (2013), "Challenges to Sustain Poland's Growth Model”, OECD Economics Department Working Papers, No. 1054, OECD Publishing.

ERO (2012), National Report 2012, Energy Regulatory Office, July.

ERO (2013), "Sprawozdanie z działalności Prezesa Urzędu Regulacji Energetyki w 2012 r”. Report of the Energy Regulatory Office.

Estrin, S., J. Hanousek, K. Evzen and J. Svejnar (2009), "The effects of privatisation on ownership in transition economies", Journal of Economic Literature, Vol. 47, No. 3, pp. 699-728.

European Commission (2003), Social Security Systems and Demographic Developments in Agriculture in the CEE Candidate Countries, Directorate General for Agriculture.

European Commission (2007), "Report on the Retail Banking Sector Enquiry", Commission Staff Working Document, No. 106.

European Commission (2008), "Executive summary and overview of the national report for Poland", http://ec.europa.eu/competition/antitrust/actionsdamages/executive_summaries/poland_en.pdf

European Commission (2012a), Assessment of the 2012 national reform programme and convergence programme for Poland, $\mathrm{COM}(2012) 323$ final.

European Commission (2012b), Enterprise and Industry SBA Fact Sheet 2012 Poland.

European Commission (2012c), Poland 2011: Telecommunication Market and Regulatory Developments.

European Commission (2013), Proposal for a regulation of the European parliament and of the Council on interchange fees for card-based payment transactions, SWD(2013)288.

Eurostat (2010), Farm Structure Survey 2010, http://epp.eurostat.ec.europa.eu/cache/ITY_SDDS/EN/ef_esms.htm

Fonteyne, W. (2007), “Cooperative Banks in Europe, Policy Issues”, IMF Working Paper, No. 07-159.

Global Competition Review (2013), Rating Enforcement 2013, May 2013.

Goh, C. and B. Javorcik (2007), "Trade Protection and Industry Wage Structure in Poland" in Globalization and Poverty, NBER, Chapters, pp. 337-72. 
Goldberg, P.K., A.K. Khandelwal, N. Pavcnik and P. Topalova (2010), "Imported Intermediate Inputs and Domestic Product Growth: Evidence from India", The Quarterly Journal of Economics, Vol. 125, No. 4, pp. 1727-67.

Hashmi, A.R. (2013), "Competition and Innovation: The inverted-U Relationship Revisited", Review of Economic and Statistics, Vol. 95, No. 5, pp. 1653-68.

IMF (2013a), “German-Central European Supply Chain Cluster Report”, IMF Country Report, No. 13/263.

IMF (2013b), "Republic of Poland: Financial System Stability Assessment”, IMF Country Report, No. $13 / 221$.

Integer (2012), "The postal market battle continues escalating! Polish postal sector on the eve of market liberalization", Press News, 10 October,

http://www1.integer.pl/biuroPrasowe/the_postal_market_battle_continues_escalating,478.html

Javorcik, B. (2004), "Does Foreign Direct Investment Increase the Productivity of Domestic Firms? In Search of Spillovers Through Backward Linkages", American Economic Review, Vol. 94, No. 3, pp. 605-27.

Johansson, A., Y. Guillemette, F. Murtin, D. Turner, G. Nicoletti, C. de la Maisonneuve, P. Bagnoli, G. Bousquet and F. Spinelli (2013), "Long-term global growth scenarios", OECD Economics Department Working Papers, No. 1000, OECD Publishing.

Kierzenkowski, R. (2008), "The Challenge of Rapidly Improving Transport Infrastructure in Poland", OECD Economics Department Working Papers, No. 640, OECD Publishing.

Koske, I., I. Wanner, R. Bitetti and O. Barbiero (2014), "The 2013 Update of the OECD Product Market Regulation Indicators: Policy Insights for OECD and non-OECD Countries", OECD Economics Department Working Papers, OECD Publishing forthcoming.

Kowalewski, O. and K. Rybinski (2011), "The hidden transformation: the changing role of the state after the collapse of communism in Central and Eastern Europe", Oxford Review of Economic Policy, Vol. 27, No. 4, pp. 634-57.

Kowalski, P., M. Büge, M. Sztajerowska and M. Egeland (2013), "State-owned enterprises: trade effects and policy implications", OECD Trade Policy Papers, No. 147, OECD Publishing.

Krol, M., (2010), "Liberalization without a Regulator. The Rail Freight Transport Market in Poland in the Years 1996-2009", Yearbook of Antitrust and Regulatory Studies, Vol. 3, No. 3, pp. 165-78.

Mayneris, F., T. Mayer and L. Py (2012), “The Impact of Urban Enterprise Zones on Establishments' Location Decisions: Evidence from French ZFUs”, CEPR Discussion Paper, No. 9074.

Megginson, W.L. and J.M. Netter (2001), "From state to market: a survey of empirical studies on privatisation", Journal of Economic Literature, Vol. 39, No. 2, pp. 321-89.

Ministry of Economy (2012), Entrepreneurship in Poland, http://www.mg.gov.pl/files/upload/9144/Entrepreneurship\%20in\%20Poland_2012.pdf

Ministry of Finance (2013), Preferencje podatkowe w Polsce 2012, http://www.finanse.mf.gov.pl/pl/abc-podatkow/preferencje-podatkowe-w-polsce 
Ministry of Justice (2014), "Draft bill amending the bill on The National Court Register and other act", http://www.sejm.gov.pl/sejm7.nsf/druk.xsp?documentId=0FA632C5B796AE87C1257C6F0039E094)

Ministry of Treasury (2013a), Ownership transformation processes - status as of 31 December 2012, http://www.msp.gov.pl/download/3/3141/2013_02_18_przeksztalcenia_zalacznik_en.pdf

Ministry of Treasury, (2013b), Poland: privatisation plan \& investment opportunities, June.

Nicoletti, G. and S. Scarpetta (2003), "Regulation, productivity and growth: OECD evidence", OECD Economics Department Working Paper No. 347, OECD Publishing.

Nicoletti, G. and S. Scarpetta (2005), "Regulation and economic performance: product market reforms and productivity in the OECD", OECD Economics Department Working Paper, No. 460, OECD Publishing.

Nickell, S. (1996), “Competition and Corporate Performance”, Journal of Political Economy, Vol. 104, No. 4 , pp. $724-46$.

OECD (2004), OECD Economic Surveys: Poland 2004, OECD Publishing.

OECD (2006), OECD Economic Surveys: Poland 2006, OECD Publishing.

OECD (2007), "Competition Policy and Concessions", Policy Brief, OECD Publishing.

OECD (2008a), OECD Economic Surveys: Poland 2008, OECD Publishing.

OECD (2008b), "The Interface between Competition and Consumer Policies", Global Forum on Competition, DAF/COMP/GF(2008)10, OECD Publishing.

OECD (2008c), OECD Territorial Reviews: Poland 2008, OECD Publishing.

OECD (2009a), State owned enterprises and the principle of competitive neutrality, Competition Law \& Policy OECD, OECD Publishing.

OECD (2009b), OECD Principles for Integrity in Public Procurement, OECD Publishing.

OECD (2010a), Economic Surveys Poland 2010, OECD Publishing.

OECD (2010b), Poland: Key Issues and Policies, OECD Studies on SMEs and Entrepreneurship, OECD Publishing.

OECD (2010c), Pricing water resources and water and sanitation services, OECD Publishing.

OECD (2011a), "Private remedies", OECD Journal: Competition Law and Policy, Vol. 11, No. 2, OECD Publishing.

OECD (2011b), Institutional and Procedural Aspects of the Relationship between Competition Authorities and Courts, and Update on Developments in Procedural Fairness and Transparency,

DAF/COMP(2011)122, OECD Publishing.

OECD (2011c), Government at a Glance, OECD Publishing. 
OECD (2011d), OECD Communications Outlook 2011, OECD Publishing.

OECD (2011e), Ten years of water sector reform in Eastern Europe, Caucasus and Central Asia, OECD Publishing.

OECD (2011f), Evaluation of agricultural policy reforms in the European Union, OECD publishing.

OECD (2011g), Bank competition and financial stability, OECD Publishing.

OECD (2012a), Competitive neutrality: maintaining a level playing field between public and private business, OECD Publishing.

OECD (2012b), Report on experiences with structural separation, Competition Committee, OECD Publishing.

OECD (2012c), Economic Surveys Poland 2012, OECD Publishing.

OECD (2012d), "Developments in Mobile Termination”, OECD Digital Economy Papers, No. 193, OECD Publishing.

OECD (2013a), Productivity database, OECD Publishing.

OECD (2013b), OECD Economic Surveys: Italy 2013, OECD Publishing.

OECD (2013c), "The size and sectoral distribution of SOEs in OECD and partner countries", Working Party on State Ownership and Privatisation Practices, DAF/CA/SOPP(2013)9/REV1.

OECD (2013d), Government at a Glance, OECD Publishing.

OECD (2013e), Investing Together, Working Effectively across Levels of Government, OECD Publishing.

OECD (2013f), OECD Communications Outlook 2013, OECD Publishing.

Palumbo, G., G. Giupponi, I. Nunziata and J. Mora Sanguinetti (2013), "Judicial Performance and its Determinants: A Cross Country Perspective”, OECD Economic Policy Papers, No. 5, OECD Publishing.

Pawlowska, M. (2012), "Competition, concentration and foreign capital in the Polish banking sector (prior and during the financial crisis)", National Bank of Poland Working Papers, No. 130.

Piszcz, A. (2012), "Still Unpopular Sanctions: Developments in Private Antitrust Enforcement in Poland After the 2008 White Paper", Yearbook of Antitrust and Regulatory Studies, Vol. 5(7), pp. 55-77.

Polish Agency for Enterprise Development (2011), "Second Chance Policy. Demand for advisory services and tools to support entrepreneurs who start a new venture after a business closure", Research commissioned by the Polish Agency for Enterprise Development.

Polish News Bulletin (2013a), "100+ professions to be deregulated”, Vol. 86, No. 7, 21 June.

Polish News Bulletin (2013b), "Treasury to increase supervision over State-owned companies”, Vol. 88, No. 2, 12 July. 
Polish News Bulletin (2013c), “Unreliable Tenderers May Lose Bid Bonds”, Vol. 90, No. 8, 20 August.

Polish News Bulletin (2014), "PM Promises Easier Procedures for New Companies”, Vol. 95, No. 22, 8 January.

Public Procurement Office (2012), Report on functioning of public procurement system in 2011, Public Procurement Office, May.

Ratnovski, L. (2013), “Competition Policy for Modern Banks”, IMF Working Paper 13/126.

Rojek, M. (2013), "Deregulating access to professions in Poland", Presentation at the workshop on Regulating access to professions: national perspectives, Brussels, 17 June.

Tompson, W. (2009), The Political Economy of Reform, Lessons from Pensions, Product Markets and Labour Markets in Ten OECD countries, OECD Publishing.

Tulibacka, M. and R. Goral (2013), “An Update on Class Actions and Litigation Funding in Poland”, unpublished Stanford University Working Paper.

Tusk, D. (2012), Exposé implementation status - as at 9 October 2012, https://www.premier.gov.pl/en/news/news/expose-implementation-status-as-at-9-october-2012.html

UOKIK (2012), "Raport o pomocy publicznej w Polsce udzielonej przedsiębiorcom w 2011 roku”, Report of the Office of Competition and Consumer Protection.

UOKIK (2013), Report on Activity 2012, Office of Competition and Consumer Protection.

UOKIK (2014), “PGNiG - UOKiK's decision”, 24 January, http://www.uokik.gov.pl/news.php?news_id=10825

UTK (2012), Polish railway market in 2011, Polish Office of Rail Transportation.

Warsaw Business Journal (2013), "Ryanair becomes the most popular airline in Poland", 3 July, http://www.wbj.pl/article-63205-ryanair-becomes-the-most-popular-airline-in-poland.html

WIK-Consult (2013), "Main Developments in the Postal Sector (2010-2013)", Study for the European Commission, Directorate General for Internal Market and Services, August.

Wise, M. (2003), "Review of competition law and policy in Poland", OECD Journal: Competition Law and Policy, Vol. 5, No. 2, pp. 83-132.

Wolszczak, G. (2009), "Airport charges regulation: the impact of the institutional structure on the regulatory process", Hertie School of Governance.

World Bank (2012), Doing Business 2013: Smarter Regulations for Small and Medium-Size Enterprises, The World Bank.

World Bank (2013), Doing Business 2014: Understanding Regulations for Small and Medium-Size Enterprises, The World Bank.

World Economic Forum (2013), Global Competitiveness Report 2013-14, Data Appendix, $\mathrm{http} / /$ www.weforum.org/issues/competitiveness-0/gci2012-data-platform/ 


\section{WORKING PAPERS}

The full series of Economics Department Working Papers can be consulted at www.oecd.org/eco/workingpapers

1124. Making the labour market work better in Poland (June 2014) by Hervé Boulhol

1123. Enhancing competition and the business environment in Hungary (June 2014) by Alvaro Pina

1122. Tackling labour mismatches and promoting mobility in Hungary (June 2014) by Stéphane Sorbe

1121. Local public finances and municipal reform in Finland (June 2014) by Christophe André and Clara Garcia

1120. The economic consequences of ageing: the case of Finland (June 2014) by Christine de la Maisonneuve, Christophe André, Clara Garcia and Vincent Koen

1119. Making the most of skills in Denmark

(June 2014) by Stéphanie Jamet and Vincent Koen

1118. Trade specialisation and policies to foster competition and innovation in Denmark (June 2014) by Müge Adalet McGowan

1117. Policies for making the Chilean labour market more inclusive (June 2014) by Aida Caldera Sanchez

1116. Spillover effects from exiting highly expansionary monetary policies

(May 2014) by Łukasz Rawdanowicz, Romain Bouis, Jérôme Brezillon, Ane Kathrine Christensen and Kei-Ichiro Inaba

1115. Economic policies and microeconomic stability: a literature review and some empirics (April 2014) by Paula Garda and Volker Ziemann

1114. How to improve Israel's health-care system (April 2014) by Philip Hemmings

1113. How to improve taxes and transfers in Israel (April 2014) by Philip Hemmings

1112. New evidence on the determinants of industrial specialisation (April 2014) by Asa Johansson and Eduardo Olaberria

1111. Economic growth from the household perspective: GDP and income distribution developments across OECD countries

(April 2014) by Orsetta Causa, Sonia Araujo, Agnès Cavaciuti, Nicolas Ruiz and Zuzana Smidova 
1110. Would a growth slowdown in emerging markets spill over to high-income countries? A quantitative assessment

(April 2014) By Patrice Ollivaud, Elena Rusticelli and Cyrille Schwellnus

1109. Short-term indicator models for quarterly GDP growth in the BRIICS: A small-scale bridge model approach

(April 2014) by Thomas Chalaux and Cyrille Schwellnus

1108. The prudential regulation of financial institutions: why regulatory responses to the crisis might not prove sufficient

(March 2014) by William R. White

1107. OECD forecasts during and after the financial crisis: a post mortem

(March 2014) by Nigel Pain, Christine Lewis, Thai-Thanh Dang, Yosuke Jin and

Pete Richardson

1106. Fairly sharing the social impact of the crisis in Greece

(January 2014) by Vassiliki Koutsogeorgopoulou, Manos Matsaganis, Chrysa Leventi and Jan-David Schneider

1105. Dividing the pie in Brazil: income distribution, social policies and the new middle class

(January 2014) by Jens M. Arnold and João Jalles

1104. New indicators of competition law and policy in 2013 for OECD and non-OECD countries (December 2013) by Enrico Alemani, Caroline Klein, Isabell Koske, Cristiana Vitale and Isabelle Wanner

1103. The effect of government debt, external debt and their interaction on OECD interest rates (December 2013) by David Turner and Francesca Spinelli

1102. The state of the banking sector in Europe

(December 2013) by Dirk Schoenmaker and Toon Peek

1101. Getting Irish youth on the job track

(December 2013) by Alberto González Pandiella

1100. New econometric estimates of long-term growth effects of different areas of public spending (December 2013) by Omar Barbiero and Boris Cournède

1099. Cross-country spillovers from fiscal consolidations

(December 2013) by Antoine Goujard

1098. Informal employment in Russia: definitions, incidence, determinants and labour market segmentation

(December 2013) by Hartmut Lehmann and Anzelika Zaiceva

1097. Capacity needs in the automobile industry in the short- to medium run

(November 2013) by Caroline Klein and Isabell Koske

1096. Environmental policies and productivity growth - a critical review of empirical findings (November 2013) by Tomasz Koźluk and Vera Zipperer 